\title{
Convenient synthesis of 1,3-dithiolane-2-thiones: cyclic trithiocarbonates as conformational locks ${ }^{1}$
}

\author{
Irina A. Dotsenko, Qinliang Zhao, Andreas H. Franz, Patrick Batoon, \\ Nataliya M. Samoshina, and Vyacheslav V. Samoshin* \\ Department of Chemistry, College of the Pacific, University of the Pacific, \\ Stockton, CA 95 211, USA \\ E-mail: vsamoshin@pacific.edu
}

DOI: $\underline{\text { http://dx.doi.org/10.3998/ark.5550190.p008.671 }}$

\begin{abstract}
A series of novel 1,3-dithiolane-2-thiones, or cyclic trithiocarbonates, has been prepared by a new simple procedure: a treatment of the corresponding epoxides with the commercially available potassium ethyl xanthogenate, $\mathrm{KSC}(\mathrm{S}) \mathrm{OEt}$. The stereochemistry of the products was determined by ${ }^{1} \mathrm{H}$ NMR and in some cases by single-crystal X-ray data. Cyclohexane-based 1,3dithiolane-2-thiones revealed a trans-fusion of the carbo- and hetero-cycles. The products obtained from the mono-substituted cyclohexene oxides demonstrated an axial position of the substituents. Thus the epoxide transformation into trithiocarbonate can be used as a method for locking cyclic compounds in unstable conformations.
\end{abstract}

Keywords: Conformational control, conformational lock, molecular switches, epoxides, 1,3dithiolane-2-thiones, cyclic trithiocarbonates

\section{Introduction}

1,3-Dithiolane-2-thiones, or cyclic trithiocarbonates, attract much attention due to their variety of useful properties. ${ }^{2,3}$ They are used as building blocks in the synthesis of new antibiotics, and as versatile ligands and polymers. ${ }^{2-6}$ Trithiocarbonates are also of commercial importance in a wide variety of applications, for example as rubber stabilizers, ore flotation agents, and additives for lubricants and fuels. ${ }^{7-9}$ Besides, they exhibit a remarkably high liver disorder suppressing effect, and hypocholesteremic, hypotriglyceridemic, radioprotective, and insecticidal activity. ${ }^{9-12}$

One of the most efficient methods for the synthesis of cyclic trithiocarbonates reported in literature is based on the reaction of epoxides with carbon disulfide $\left(\mathrm{CS}_{2}\right)$ in presence of a base and/or a catalyst. ${ }^{2,5-8,10-14}$ However, these procedures often suffer from low yields and poor selectivity. Depending on the catalyst and reaction conditions, a variety of products can be 
formed. In addition, use of the volatile, inflammable and toxic carbon disulfide is definitely a serious disadvantage.

Herein we report a new procedure for the synthesis of 1,3-dithiolane-2-thiones: a treatment of epoxides with commercially available potassium ethyl xanthogenate, KSC(S)OEt (for a preliminary communication see ref. 1) The procedure is simple, safe, inexpensive, and relatively fast. It does not require high pressure and catalyst, and often gives 1,3-dithiolane-2-thione as the only product in good to moderate yields. The mechanism and stereochemistry of the reaction are discussed.

When cyclohexene oxide was used as a starting material in catalytic reaction with $\mathrm{CS}_{2}$, the newly formed five-membered cyclic trithiocarbonate was trans-fused to the cyclohexane ring. ${ }^{2}$ Our modified procedure has the same stereochemical outcome. When it is applied to epoxides of substituted cyclic alkenes, the substituent(s) on the ring could be forced to adopt a sterically unfavourable axial position. Thus, the five-membered trithiocarbonate ring can serve as a lock for unfavourable conformations. We suggest this approach in addition to a set of other conformational locks (acetals, ortho-esters, urethanes, etc.) that have previously been used in various stereoselective syntheses. ${ }^{15,16}$

\section{Results and Discussion}

\section{Synthesis of trithiocarbonates}

In the course of our studies on the cleavage of epoxides with sulfur nucleophiles, ${ }^{17,18}$ we found that treatment with potassium xanthogenate transformed epoxides into 1,3-dithiolane-2-thiones (cyclic trithiocarbonates) in good to moderate yields. ${ }^{1}$ The procedures described previously for such a transformation used carbon disulfide in presence of a base and/or catalyst, and included an in situ formation of a xanthogenate or a similar intermediate, and then its reaction with an epoxide $^{2,5-8,10-14}$ (for a detailed critical consideration of the literature data see ref. 2). Thus, our modified procedure eliminates the most inconvenient step, which used the toxic, volatile and inflammable $\mathrm{CS}_{2}$, by employing a safe commercially available reagent.

We carried out the reaction of cyclohexene oxide with $\mathrm{KSC}(\mathrm{S}) \mathrm{OEt}$ (Scheme 1) under various conditions as summarized in Table 1.

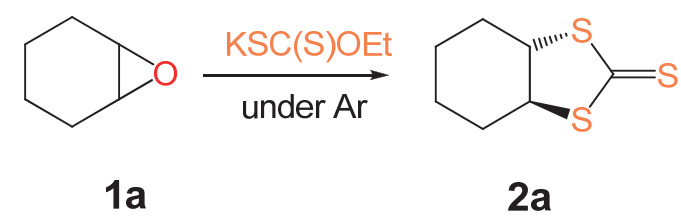

Scheme 1. Synthesis of trans-hexahydro-1,3-benzodithiole-2-thione (2a) 
Table 1. Reaction of cyclohexene oxide (1a) with potassium ethyl xanthogenate (Scheme 1)

\begin{tabular}{ccccccc}
\hline Entry & $\begin{array}{c}\text { KSC(S)OEt:epoxide } \\
\text { mole ratio }\end{array}$ & Solvent & $\begin{array}{c}\text { Temp } \\
\left({ }^{\circ} \mathrm{C}\right)\end{array}$ & $\begin{array}{c}\text { Time } \\
(\mathrm{h})\end{array}$ & $\begin{array}{c}\text { Conversion } \\
(\%)\end{array}$ & $\begin{array}{c}\text { Yield } \\
\text { of 2a } \\
(\%)\end{array}$ \\
\hline 1 & $1: 1$ & $\mathrm{EtOH}$ & 35 & 12 & 100 & 37 \\
2 & $1: 1$ & $\mathrm{MeOH}$ & 35 & 12 & 100 & 39 \\
3 & $2: 1$ & $\mathrm{MeOH}$ & 35 & 3.5 & 100 & 73 \\
4 & $2: 1$ & $\mathrm{MeOH}$ & 35 & 12 & 100 & 51 \\
5 & $2: 1$ & $\mathrm{MeOH}$ & 20 & 3.5 & 77 & 42 \\
6 & $3: 1$ & $\mathrm{MeOH}$ & 35 & 3.5 & 100 & 54 \\
7 & $5: 1$ & $\mathrm{MeOH}$ & 35 & 3.5 & 100 & 47 \\
\hline
\end{tabular}

The isolated yield of the product was dependent on the molar ratio $\mathrm{KSC}(\mathrm{S}) \mathrm{OEt}$ to epoxide. The best result was achieved when the ratio was 2:1 (entry 3). Upon increase of the ratio to 3:1 and 5:1 the yield decreased, but no starting epoxide was recovered (entries 6,7). Most likely the yield declined due to side reactions of epoxide such as an intermediate/product polymerization. Upon increase of the reaction time the yield decreased (experiment 4). Therefore it was important to monitor the reaction by TLC and to stop it immediately after the complete conversion of epoxide. A reaction temperature of $35-40{ }^{\circ} \mathrm{C}$ was found to be optimal, because a lowering of temperature reduced the yield of the product significantly (experiment 5 ).

Because the conditions of experiment 3 in Table 1 gave the best yield, they were used as standard conditions for the synthesis of a series of trithiocarbonates (Table 2). The starting epoxides were prepared by reaction of corresponding commercially available alkenes with $m$ CPBA.

In some experiments, the reaction yielded intermediate products - thiiranes (see discussion of the mechanism below) or the products of polymerization.

We also explored the possibility of aromatization of the S-substituted cyclohexane rings by treatment of the compounds 2 with $\mathrm{Br}_{2}$, NBS, or DDQ. ${ }^{22-25}$ However, we obtained the products of oxidation (sulfur replacement) 3 (Scheme 2). Thus, these reagents may be added to the toolbox of other oxidizers used previously for the transformation of 1,3-dithiolane-2-thiones into 1,3-dithiolan-2-ones. ${ }^{2,3,26-29}$ 
Table 2. Reaction of various epoxides with potassium ethyl xanthogenate. ${ }^{a}$

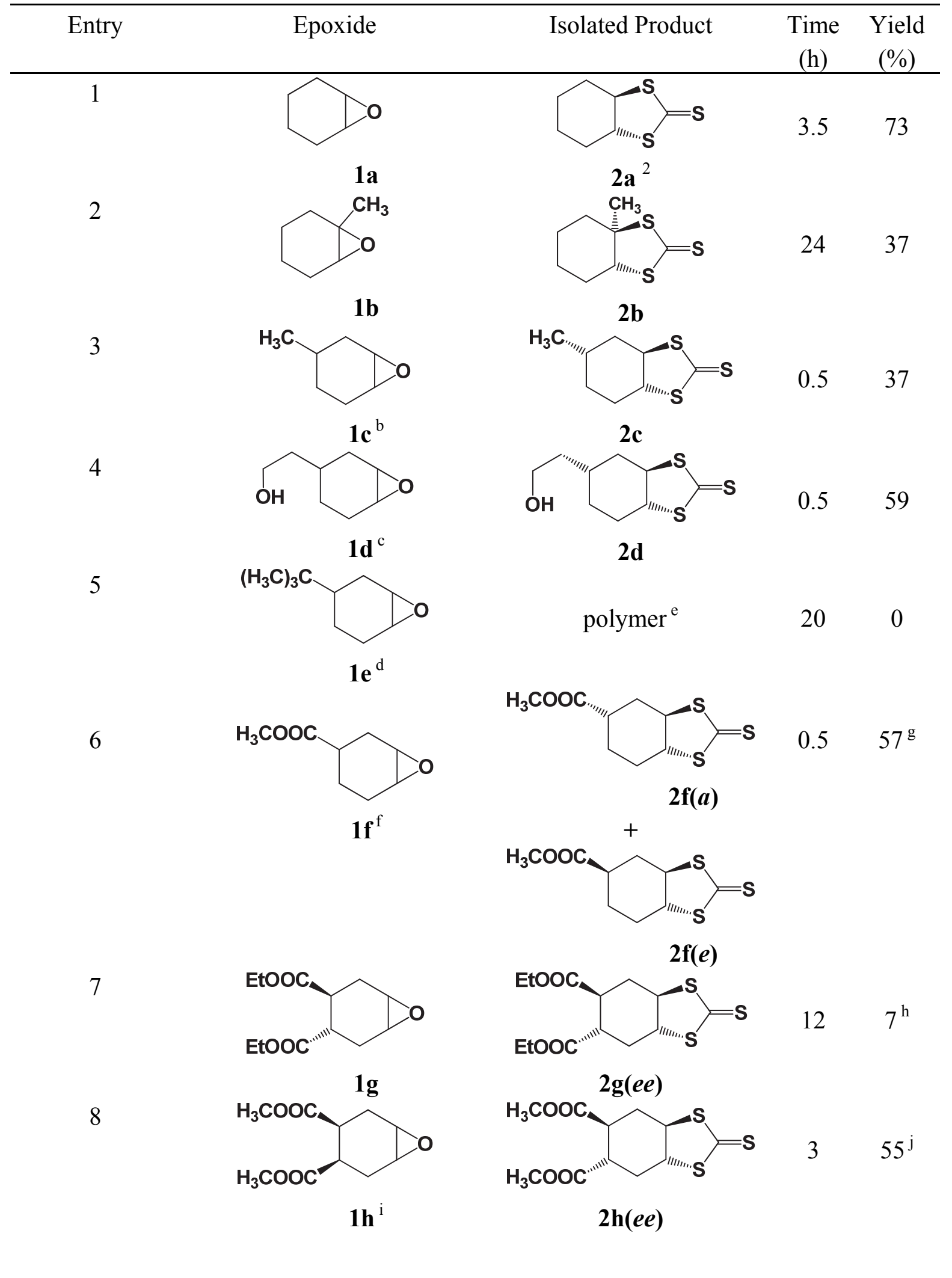


Table 2. Continued

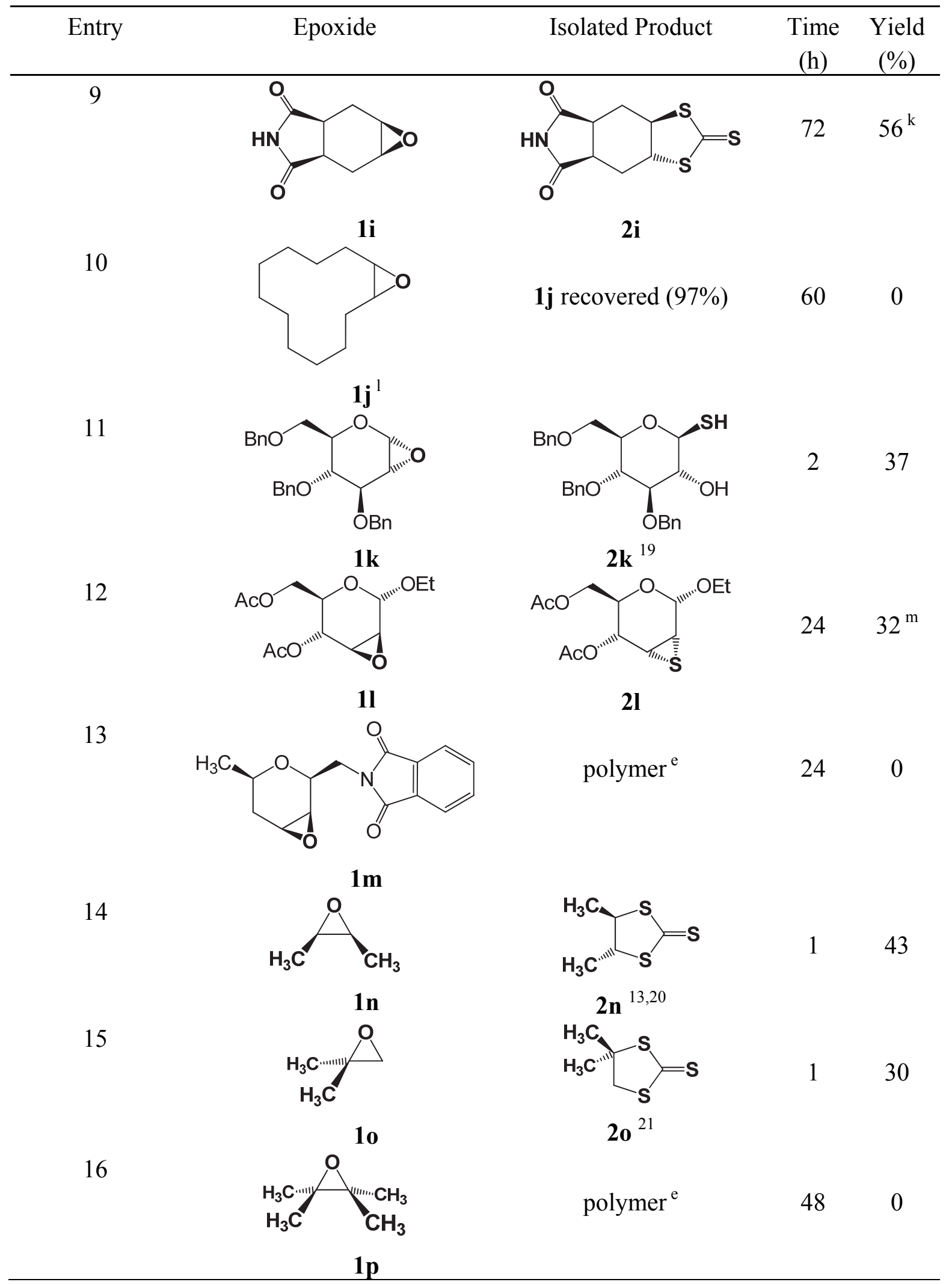


Table 2. Continued

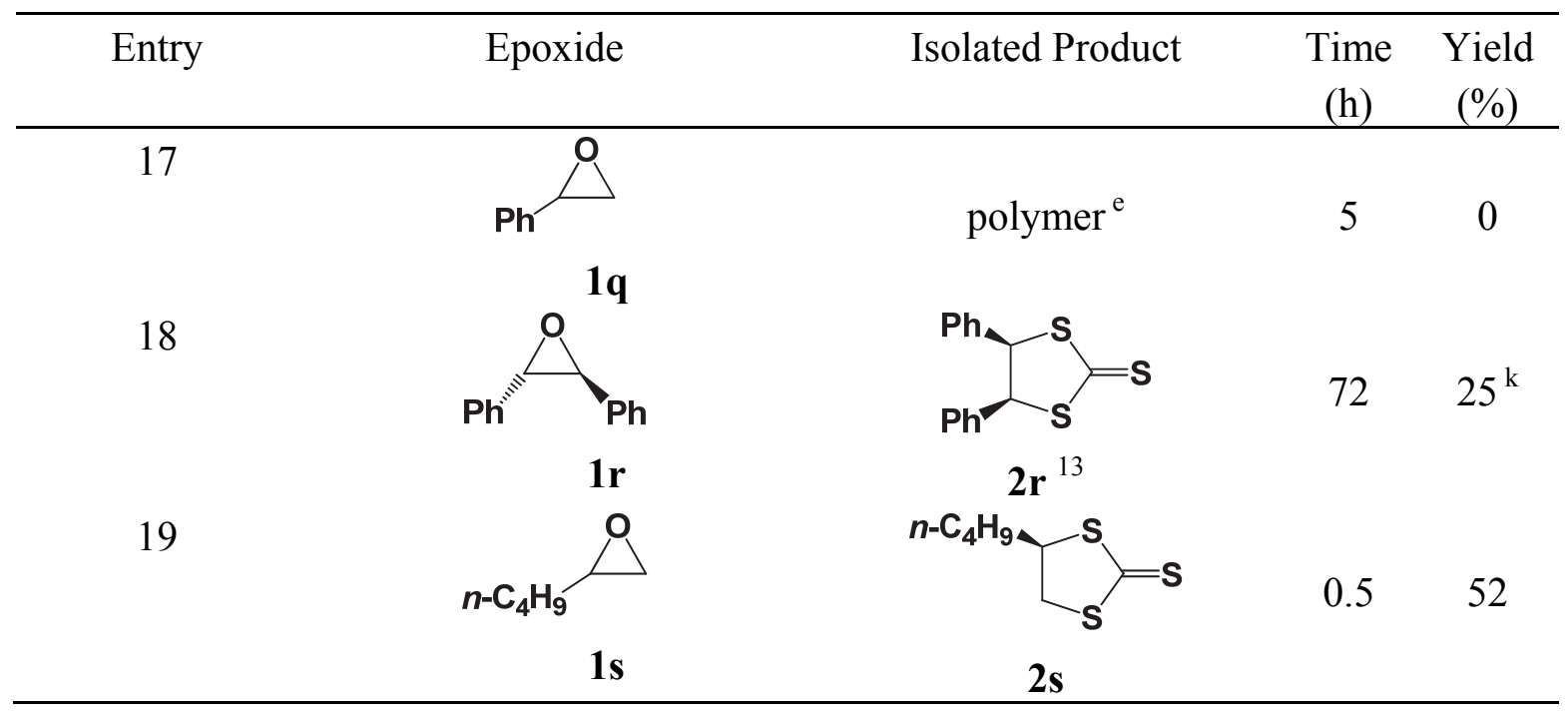

${ }^{\text {a }}$ Epoxide-reagent ratio $1: 2$; solvent - methanol; 35-45 ${ }^{\circ} \mathrm{C}$; yields are not optimized; the reactions were terminated after complete consumption of epoxide (by TLC) ${ }^{\mathrm{b}}$ anti:syn $=1.3: 1{ }^{\mathrm{c}}$ anti:syn $=1: 1$;

${ }^{\mathrm{d}}$ anti:syn $=1: 2 ;{ }^{\mathrm{e}}$ Only polymeric products; no starting epoxide recovered; ${ }^{\mathrm{f}}$ Pure anti or syn-isomer, or the mixture anti:syn $=1: 1$; ${ }^{\mathrm{g}}$ After $0.5 \mathrm{~h}$ the ratio of products $\mathbf{2 f}(\boldsymbol{a}): \mathbf{2} \mathbf{f}(\boldsymbol{e})$ was (2.2-3.3):1; after 2-3 h the ratio was 1:1.3; ${ }^{\mathrm{h}}$ In EtOH; the major product was a polymer; ${ }^{\mathrm{i}}$ Pure anti or syn-isomer (complete conversion in $2 \mathrm{~h}$ and $3 \mathrm{~h}$, respectively); ${ }^{j}$ Two diastereomers, $\mathbf{2 h}(\boldsymbol{e e})$ and $\mathbf{2 h}(\boldsymbol{e a})$, in the ratio $10: 1$; ${ }^{\mathrm{k}}$ Reaction time $72 \mathrm{~h}$; after $15 \mathrm{~h}$ thiirane was isolated as a major product; ${ }^{1}$ A mixture of cis and transisomers; ${ }^{\mathrm{m}}$ After re-acetylation.

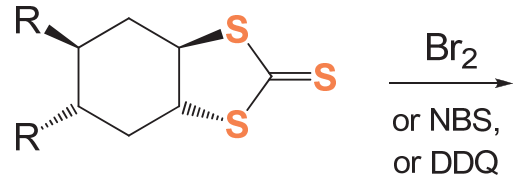

$\mathrm{R}=\mathrm{H}$

$\mathrm{R}=\mathrm{COOCH}_{3}$
$2 a$

$2 \mathrm{~h}(e e)$<smiles>[R]C1CC2SC(=O)S[C@@H]2CC1[R]</smiles>

$3 a$

$3 h(e e)$

Scheme 2. Oxidation of trithiocarbonates 2.

\section{Stereochemistry of products}

The structures of all compounds were determined by ${ }^{1} \mathrm{H}$ NMR, ${ }^{13} \mathrm{C}$ NMR and HRMS analysis. The vicinal coupling constants ${ }^{3} J_{\mathrm{HH}}$ between protons attached to the cyclohexane moiety are strongly conformation-dependent, which allows an assignment of the predominant conformation and an estimation of the position of conformational equilibrium. ${ }^{30}$ For the products with nonsymmetrical molecules, most coupling constants in ${ }^{1} \mathrm{H}$ NMR could be measured directly from the corresponding multiplets assuming the first order of spectra (for methodology see ref. 31). The 
large vicinal coupling constants between the cyclohexane protons $\mathrm{H} 3 \mathrm{a}$ and $\mathrm{H} 7 \mathrm{a}$ geminal to the sulphur atoms (12.1-12.4 Hz) proved unambiguously the trans-diaxial position of these protons and, correspondingly, the trans-diequatorial position of the sulphur atoms in the cyclohexane derivatives 2c - 2i (Figure 1). This means a trans-fusion of two rings, which has also been shown recently by X-ray analysis for the compound $\mathbf{2 a}{ }^{2}$ The configuration of remote substituents was also established from the couplings of their geminal protons. Thus, the couplings of H5 in the product $2 \mathbf{f}(\boldsymbol{e})$ (triplet of triplets with ${ }^{3} J_{\mathrm{HH}}$ of $12.3 \mathrm{~Hz}$ and $3.8 \mathrm{~Hz}$ ) indicated an equatorial position of the methoxycarbonyl group, while all the couplings of H5 in the stereoisomer $2 \mathbf{f}(\boldsymbol{a})$ were small $\left({ }^{3} J_{\mathrm{HH}} \approx 2.5-5.0 \mathrm{~Hz}\right)$ indicating an axial position of the substituent (Figure 1). The axial position of methyl group in the compound $\mathbf{2 c}$ resulted in small couplings of H5, and was also confirmed by NOE with H3a (Figure 1).

The coupling constants in the half-chairs of epoxides and thiiranes are not characteristic, therefore we used ROESY and STEP-NOESY techniques ${ }^{32,33}$ to establish or confirm the configuration of these compounds (Figure 2; for the details see Supplementary data). The STEPNOESY technique makes use of optimized 1D-pfg-TOCSY magnetization transfer from a wellseparated signal in the spectrum to a neighbouring proton in a crowded spectral region for a subsequent 1D-pfg-NOESY irradiation. When literature data were available, our results confirmed the assignments made previously (for instance, for epoxide 11). However, in case of a novel compound 1i (the major syn-product of epoxidation) this approach was inefficient because of conformational peculiarities, and we had to transform 1i into methoxycyclohexanol $\mathbf{4}$ in order to assign its configuration unambiguously (Scheme 3; see Supplementary data).

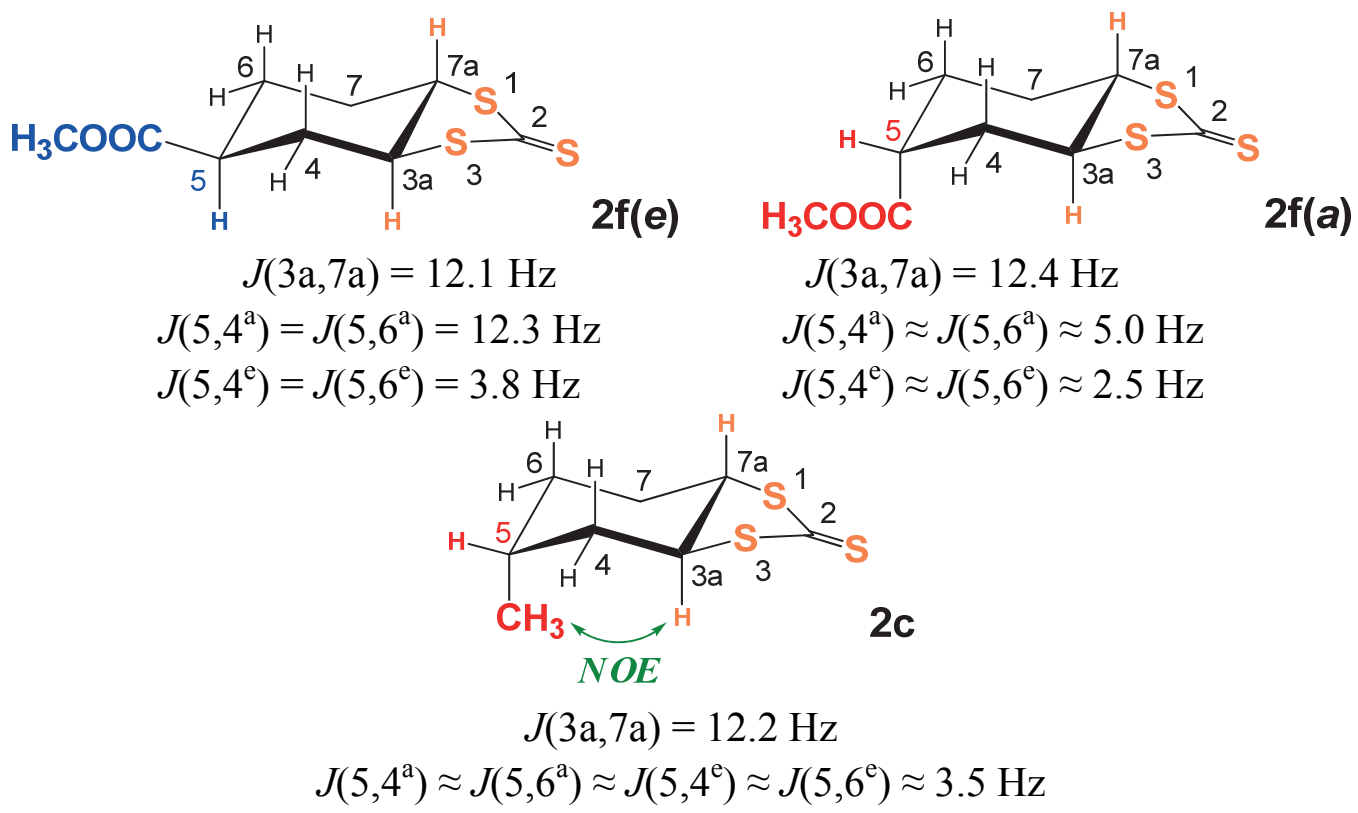

Figure 1. Examples of stereochemical assignment for cyclohexano-trithiocarbonates by ${ }^{1} \mathrm{H}$ NMR. 


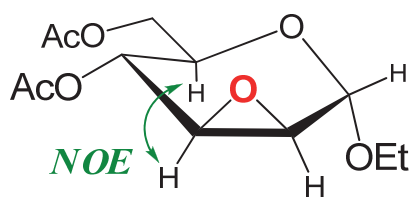

11

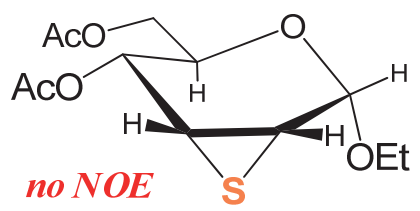

2|

Figure 2. Examples of stereochemical assignment for epoxides and thiiranes by 1D-pfg-ROESY and 1D-pfg-STEP-NOESY experiments.
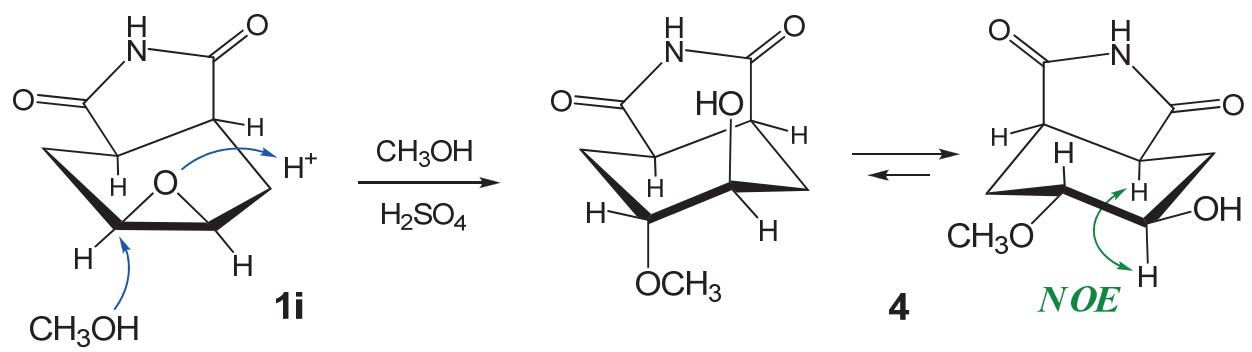

Scheme 3. Acid-catalyzed methanolic cleavage of epoxide 1 i.

The single-crystal X-ray analysis has been performed for the products $2 \mathbf{f}(\boldsymbol{a}), \mathbf{2 f}(\boldsymbol{e}), \mathbf{2} \mathbf{h}(\boldsymbol{e} \boldsymbol{e}), \mathbf{2} \mathbf{i}$, and $\mathbf{3 h}$ (Figures 3-7). Similar to the published research on compound $\mathbf{2 a},{ }^{2}$ the analysis was complicated by the extremely small size and fiber-like shape of the crystals, necessitating the use of synchrotron radiation.

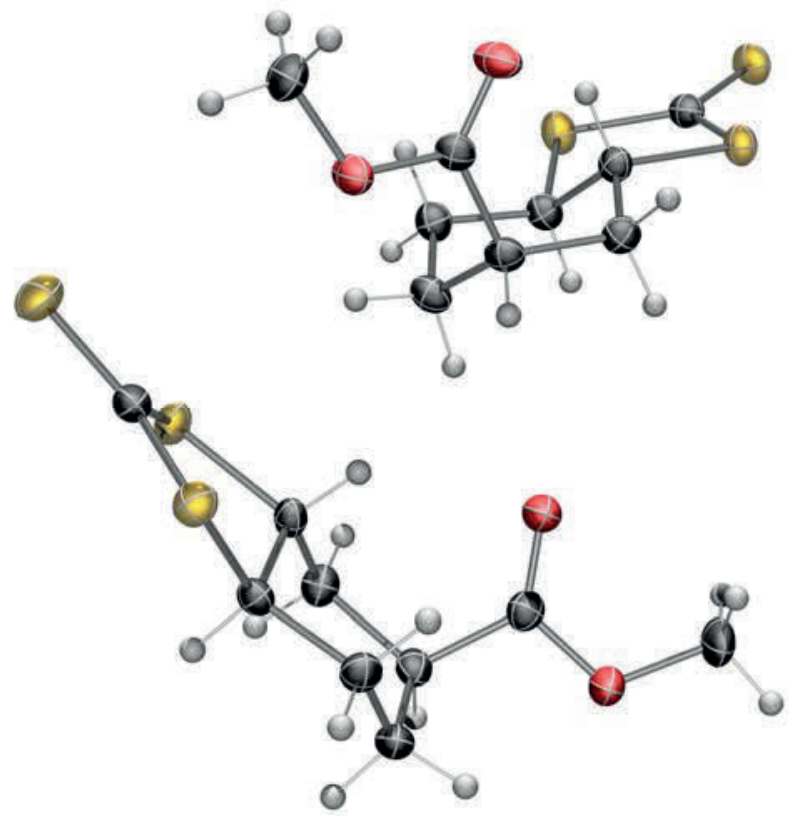

Figure 3. X-ray crystal structure of compound $\mathbf{2 f}(\boldsymbol{a})$ with thermal ellipsoids set at the $50 \%$ probability level for non-H atoms (crystals were grown from $\mathrm{MeOH}$ ). There are two molecules per asymmetric unit. 

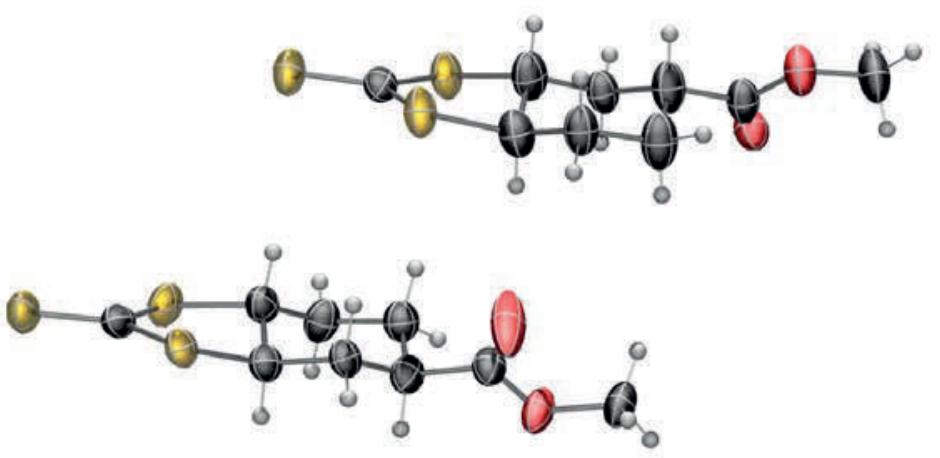

Figure 4. X-ray crystal structure of compound $\mathbf{2 f}(\boldsymbol{e})$ with thermal ellipsoids set at the $50 \%$ probability level for non-H atoms (crystals were grown from $\mathrm{MeOH}$ ). There are two molecules per asymmetric unit.

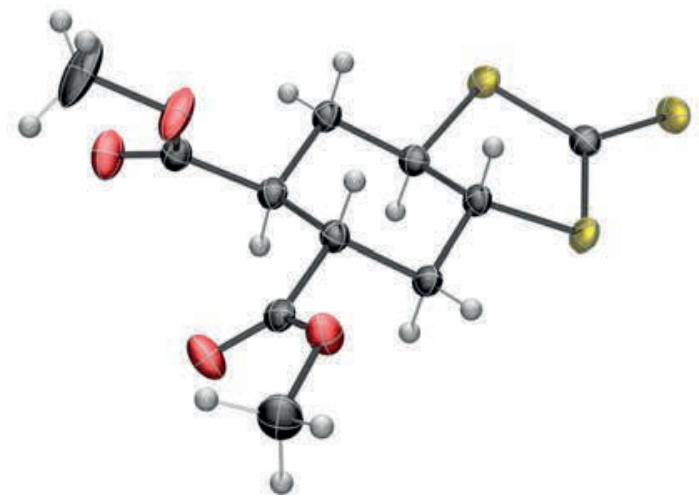

Figure 5. X-ray crystal structure of compound $\mathbf{2 h}(\boldsymbol{e e e})$ with thermal ellipsoids set at the $50 \%$ probability level for non-H atoms (crystals were grown from $\mathrm{MeOH}$ ).

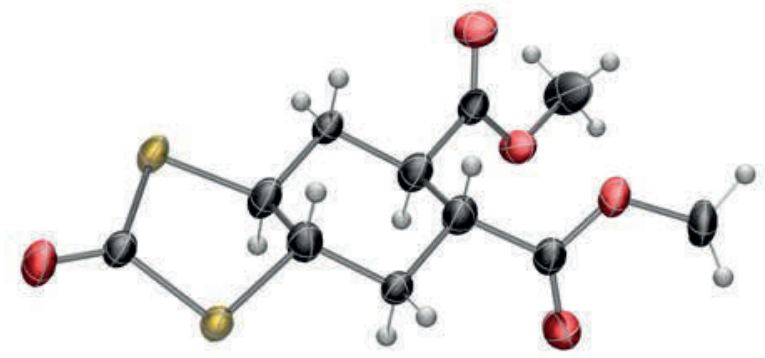

Figure 6. X-ray crystal structure of compound $\mathbf{3 h}$. Thermal ellipsoids set at the $50 \%$ probability level for non-H atoms (crystals were grown from $\mathrm{MeOH}$ ). 

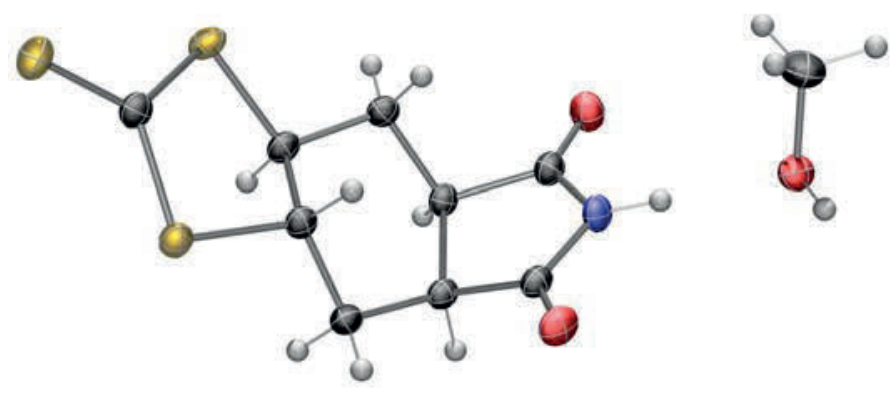

Figure 7. X-ray crystal structure of compound $2 \mathbf{i}$. Thermal ellipsoids set at the $50 \%$ probability level for non-H atoms (crystals were grown from $\mathrm{MeOH}$ ).

The X-ray data clearly demonstrate a chair conformation of the cyclohexane rings, a trans ring fusion, a nearly planar heterocycle, and in case of $\mathbf{2 f}(\boldsymbol{a})$ an axial position of the substituent. Noteworthy, the molecules of racemic compound $2 \mathbf{f}(\boldsymbol{a})$ are paired in asymmetric unit, and the components of the pair have the same configuration (Figure 3). The same kind of stereoselection occurs in case of compound $\mathbf{2 f}(\boldsymbol{e})$ (Figure 4$)$.

\section{Mechanism and stereochemistry of the reaction}

As described above, the ${ }^{1} \mathrm{H}$ NMR and X-ray data showed that all the obtained cyclohexanotrithiocarbonates were trans-isomers with equatorial position of both sulphur atoms. This requires an inversion of configuration at one of the epoxide carbons during the reaction. The configuration at the second epoxide carbon seems to remain the same as in the substrate, although the original oxygen is replaced by sulphur. This implies a double inversion at the second carbon. A plausible mechanism addressing these major peculiarities is presented in Scheme 4 for the case of mono-substituted cyclohexene epoxides. Similar, although less complete mechanistic considerations were published earlier for the formation of trithiocarbonates from the epoxides of non-cyclic alkenes using carbon disulfide in presence of a base., ${ }^{2,13,14}$

The key steps include the cleavage of epoxide 1 by xanthogenate anion, then cyclization of the intermediate 5 into the trans-fused bicyclic structure 6, which requires a transfer of the substituent $\mathrm{R}$ into a sterically strained axial position (Scheme 4). Then $\mathbf{6}$ may eliminate ethoxide ion and give 1,3-oxathiolane-2-thione 7 (route $a$ ). We did not isolate these compounds, but the formation of some 1,3-oxathiolane-2-thiones in certain conditions was observed previously. ${ }^{2,5,6,14}$ It is also known that these compounds react with excess carbon disulfide to give trithiocarbonates. ${ }^{2,6}$ Apparently, in our case the subsequent addition of a nucleophile (Nuc = $\mathrm{EtOCS}_{2}^{-}, \mathrm{EtO}^{-}$, or $\mathrm{MeO}^{-}$from the solvent) to probable intermediates 7 occurred quickly and caused cleavage of the heterocycle. An alternative detour $(b)$ seems to be also possible. ${ }^{13}$ Both ways include an intramolecular substitution leading to thiirane $\mathbf{8}$, where the group $\mathrm{R}$ occupies again a more relaxed and stable equatorial position. We isolated thiirane $\mathbf{2} \mathbf{I}$ as a major product in reaction of epoxide $\mathbf{1 l}$ (entry 12 in Table 2). The epoxides $\mathbf{1 i}$ and $\mathbf{1 r}$ (entries 9 and 18 in Table 2) 
produced mostly the corresponding thiiranes after 15-16 h, but finally gave trithiocarbonates when the time was extended to $72 \mathrm{~h}$. Other researchers also reported isolation of thiiranes in certain conditions, ${ }^{2,6,34}$ and the reaction of some thiiranes with carbon disulfide and base towards trithiocarbonates was described previously. ${ }^{21,34,35}$ Noticeably, the configuration of the threemembered cycle in $\mathbf{8}$ is opposite to the configuration of the starting epoxide $\mathbf{1}$.

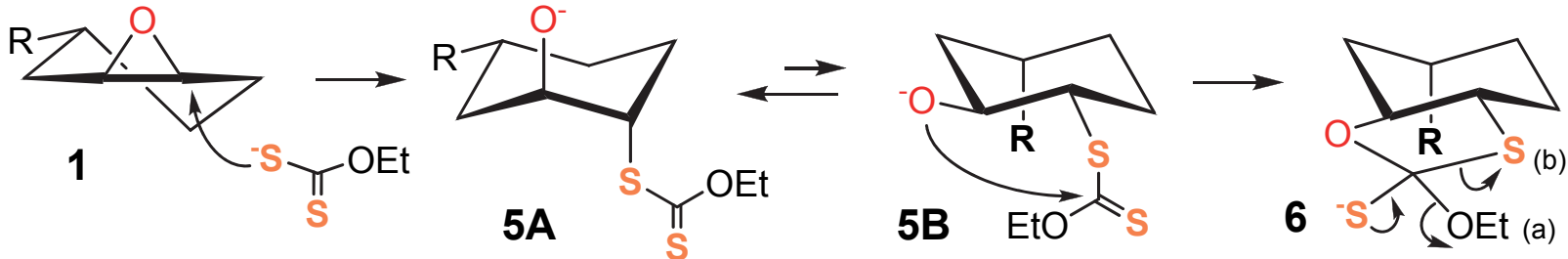

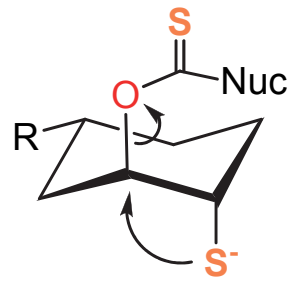<smiles>[R]C1C2CCC(CC2[S-])C1OC(=S)N(C)CCCC</smiles>

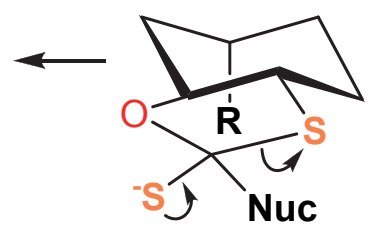

Nuc $^{-}$

(a) $1 /$

(b)
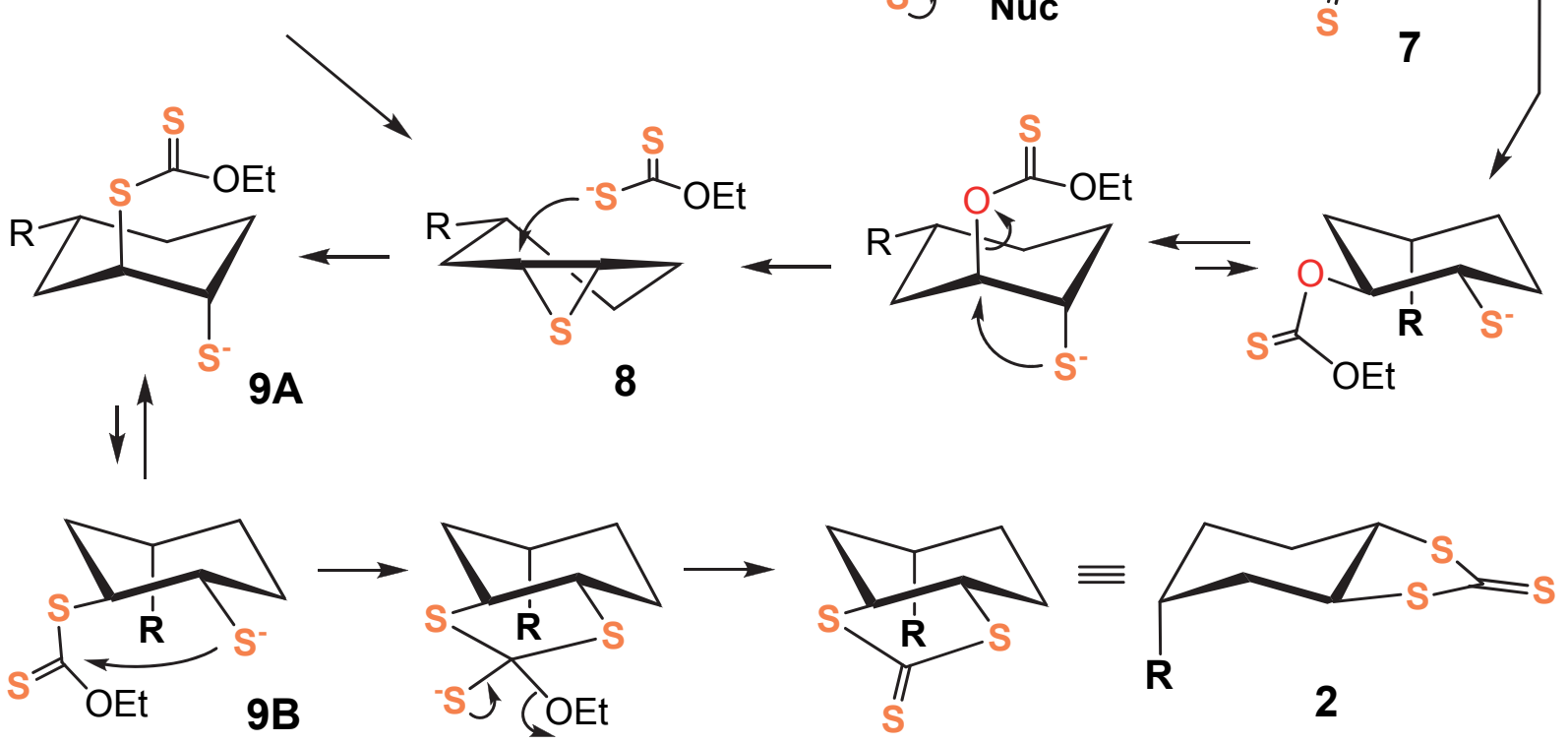

Scheme 4. Plausible mechanism for the formation of cyclic trithiocarbonates.

The thiiranes 8 (Scheme 4) are in turn subjected to nucleophilic cleavage by xanthogenate anion, followed by yet another cyclization, which forces the group $\mathrm{R}$ again into the sterically strained axial position. Despite this strain, the resulting 1,3-dithiolane-2-thiones 2 must be much less susceptible to addition of nucleophiles than their analogues 7 , and they have been isolated in most cases as the major products of reaction. Thus, the monosubstituted cyclohexene oxides 1c, 1d and $\mathbf{1 f}$ (entries 3, 4 and 6 in Table 2) yielded trithiocarbonates $2 \mathbf{c}, \mathbf{2 d}$ and $\mathbf{2 f}(\boldsymbol{a})$ respectively, with an axial substituent $\mathrm{R}$ (Figures 1, 3). According to the suggested mechanism, the 
configuration of $\mathbf{2}$ does not depend on the configuration of the starting epoxide 1 (syn- or antiposition of $\mathrm{R}$ and $\mathrm{O}$ ). Indeed, when a mixture of diastereomeric epoxides was used (entries 3, 4 in Table 2), only one product was isolated.

The transfer of substituent $\mathrm{R}$ into a sterically strained axial position is a barrier that occurs twice on the way of reaction in the case of epoxycyclohexanes and similar epoxides. It has to be overcome in conformational interconversions $\mathbf{5 A} \rightarrow \mathbf{5 B}$ and $\mathbf{9 A} \rightarrow \mathbf{9 B}$. The second transition is more difficult, because the form 9B must be additionally destabilized by a substantial gaucherepulsion between two equatorial atoms of sulfur as it was found in trans-1-RS-2-R'Scyclohexanes. ${ }^{36,37}$ This can explain why the reaction proceeds only up to thiirane in the case of sterically loaded epoxide 11 (entry 12 in Table 2), or can be stopped at the thiirane step in the case of epoxides 1i and 1r (entries 9 and 18). Similarly, steric strain in reaction intermediates prevented transformation of steroid thiiranes into trithiocarbonates (with one questionable exception). ${ }^{35}$ No trithiocarbonate or even thiirane was isolated in the reactions of 4-tbutylcylohexene oxide 1e (mixture of stereoisomers; entry 5) and cis-2,6-disubstituted epoxytetrahydropyran $\mathbf{1 m}$ (entry 13), which produced only polymeric side products. Obviously, it is very difficult to force the bulky $t$-butyl group or the $c i s$-oriented substituents into axial/syndiaxial positions already at the step of intermediate $5 \mathbf{B}$.

The studied reaction is sensitive to steric hindrance in general. Thus, no trithiocarbonate was obtained from the epoxycyclododecane $\mathbf{1 j}$ (entry 10 in Table 2). The simple dimethyl oxiranes 1n and 10 (entries 14 and 15) produced the corresponding trithiocarbonates in moderate yields, while the yield from the bulkier diphenyl oxirane 1r (entry 18) was much lower, and the tetramethyl oxirane 1p (entry 16) gave no product at all. As described earlier, the gemdimethyloxirane 10 and trimethyloxirane gave no product in catalytic reaction with carbon disulfide. ${ }^{2}$ However, the absence of steric hindrance may be also harmful because of fast side reactions: thus, styrene oxide 1q (entry 17) produced only a polymer. Evidently, this polymerization is related to the benzylic moiety, because the structurally similar epoxide $1 \mathbf{s}$ gave the expected product $2 \mathrm{~s}$ (entry 19).

Monosubstituted cyclohexene oxide $\mathbf{1 f}$ with $\mathrm{R}=\mathrm{COOMe}$ (entry 6 , Table 2 ) did not produce a single product $2 \mathbf{f}(\boldsymbol{a})$, but yielded a mixture of diastereomers $2 \mathbf{f}(\boldsymbol{a})$ and $2 \mathbf{f}(\boldsymbol{e})$ with axial and equatorial positions of the ester group, respectively (Figures 1, 3,4). The ratio of diastereomers was highly dependent on the time of reaction. After $0.5 \mathrm{~h}$ the ratio of products $2 \mathbf{f}(\boldsymbol{a}): \mathbf{2 f}(\boldsymbol{e})$ in their mixture purified by column chromatography was (2.2-3.3): 1 by ${ }^{1} \mathrm{H}$ NMR, while after $2-3 \mathrm{~h}$ the ratio almost inverted to $1: 1.3$. The longer time of reaction also decreased the overall yield from $57 \%(0.5 \mathrm{~h})$ to $43-48 \%(2 \mathrm{~h})$. This reaction was performed with pure syn- or anti-isomer of epoxide 1f, or with their 1:1 mixture, and always produced approximately the same proportion of products regardless of the starting stereochemistry. Evidently, due to relative acidity of $\alpha$-proton H5, a base-catalyzed epimerization of the expected ester $\mathbf{2} \mathbf{f}(\boldsymbol{a})$ have occurred in the course of reaction, and the more stable diastereomer $\mathbf{2} f(e)$ was formed. This hypothesis was confirmed by conversion of pure $2 \mathbf{f}(\boldsymbol{a})$ into a mixture of diastereomers $2 \mathbf{f}(\boldsymbol{a})$ and $\mathbf{2 f}(\boldsymbol{e})$ (1:1.3) after $72 \mathrm{~h}$ at $40{ }^{\circ} \mathrm{C}$ with one equivalent of $\mathrm{KSC}(\mathrm{S}) \mathrm{OEt}$ (Scheme 5). Assuming this is a ratio at equilibrium, 
the equatorial form $2 \mathbf{f}(\boldsymbol{e})$ is $0.7 \mathrm{~kJ} / \mathrm{mol}$ more stable than the axial $\mathbf{2 f}(\boldsymbol{a})$ in the conditions of reaction.

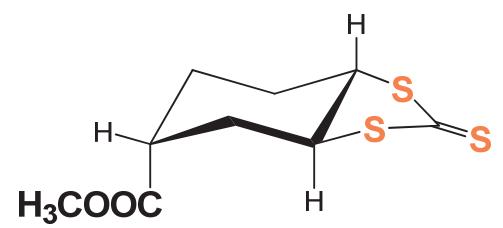

2f(a)

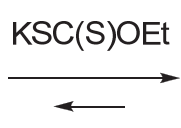

$\longleftarrow$

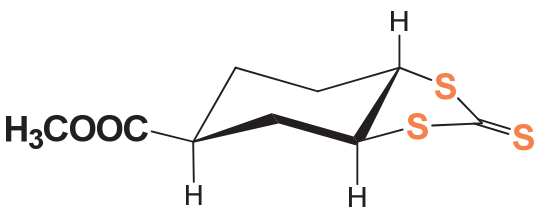

2f(e)

Scheme 5. Base-induced epimerization of the product $\mathbf{2 f}(\boldsymbol{a})$ with axial ester group.

We noticed that the epimerization of the final product $\mathbf{2 f}(\boldsymbol{a})$ with $\mathrm{KSC}(\mathrm{S}) \mathrm{OEt}$ (Scheme 5) required a longer time than that observed in the reaction of starting epoxides under the same conditions (that is in presence of $\mathrm{EtOCS}_{2}^{-}, \mathrm{EtO}^{-}$, or $\mathrm{MeO}^{-}$from the solvent). This may indicate that a faster $\alpha$-deprotonation occurs intramolecularly within one or several intermediates of the reaction, when $\alpha$-proton happens to be in a vicinity of an alcoholate or thiolate anion (Scheme 4).

The results obtained with the cyclohexene oxides $\mathbf{1 g}$ and $\mathbf{1 h}$ bearing two ester-groups also confirmed the proposed epimerization. Thus the cis-disubstituted epoxide $\mathbf{1 h}$ (entry 8 ) yielded two diastereomers, $\mathbf{2 h}(\boldsymbol{e e})$ and $\mathbf{2 h}(\boldsymbol{e a})$, in the ratio $10: 1$ (by $\left.{ }^{1} \mathrm{H} \mathrm{NMR}\right)$. The formation of the allequatorial $\mathbf{2 h}(\boldsymbol{e e})$ (Figure 5) can be explained by epimerization of the initially formed diastereomer $\mathbf{2 h}(\boldsymbol{e a})$ containing one axial ester group. In the case of trans-disubstituted epoxide $1 \mathrm{~g}$ (entry 7, Table 2), a polymer was mostly obtained, and only small amount of the product $\mathbf{2 g}(\boldsymbol{e} e)$ was isolated. The configuration of both groups COOEt in the latter compound was opposite to what should have been expected. This can be explained by the relative instability of the expected product with both ester groups in axial positions, and by the base-catalyzed epimerization of these substituents.

\section{Trithiocarbonate ring as a conformational lock}

Control of molecular conformation is a powerful way to modulate the physical, chemical and biological properties of compounds. It can be achieved by a shift of conformational equilibrium towards unusual (relatively unstable) forms via modification of substituents or construction of

bridged structures. ${ }^{15,16}$ The synthesis of cyclic trithiocarbonates from epoxides is, in fact, a construction of a bridge that affixes one of possible conformations. Moreover, the stereochemical course of the reaction (the inversion of configuration at one of the former epoxide carbons and the double inversion at the second carbon) forces the structure to perform a flip into a conformation alternative to an original one. It was shown previously that the similar procedure with $\mathrm{CS}_{2}$ as a reagent transformed the epoxides of cis-alkenes into trithiocarbonates with transarrangement of substituents. ${ }^{13}$ We observed the same result in reactions of epoxides $\mathbf{1 n}$ and $\mathbf{1 r}$ (entries 14 and 18 in Table 2). When our procedure was applied to epoxides of substituted cyclic alkenes, these substituent(s) were forced to adopt a sterically unfavourable axial position (see 
above). Thus, the five-membered ring of trithiocarbonate can serve as a lock for unfavourable conformations. This lock is powerful enough to make a methyl group axial, which requires 7.3 $\mathrm{kJ} / \mathrm{mol},{ }^{38}$ but fails to do the same with $t$-butyl $\left(\sim 20 \mathrm{~kJ} / \mathrm{mol}^{38}\right)$. The lock can be subsequently removed or cleaved by reduction ${ }^{4,13,26,27}$ or hydrolysis ${ }^{27}$ of trithiocarbonates to dithiols. We suggest this approach as a potentially useful addition to a set of other conformational locks (acetals, ortho-esters, urethanes, etc.) that have been used in various syntheses previously. ${ }^{15,16}$ In particular, the results of our study clearly point to a possible application of the trithiocarbonate lock for a stereoselective epimerization of ester substituents in basic conditions.

\section{Conclusions}

A simple and convenient procedure for the selective synthesis of 1,3-dithiolane-2-thiones (cyclic trithiocarbonates) from epoxides has been developed. The mechanism and stereochemistry of the reaction have been studied. The formation of cyclic trithiocarbonates can be used to lock unstable conformations.

\section{Experimental Section}

General. The chemicals used in this study were purchased from commercial sources (SigmaAldrich, TCI) and used without additional purification. All solvents were purified by conventional techniques prior to use. Column chromatography was performed on silica gel (40$75 \mu \mathrm{m}$, Sorbent Technologies) and aluminum oxide (activated basic, 58 , Aldrich). The reactions were monitored by TLC on silica gel $2.5 \times 7.5 \mathrm{~cm}$ plates, J. T. Baker (visualization by staining with $\mathrm{KMnO}_{4}$-sulfuric acid), or alumina $8 \times 2 \mathrm{~cm}$ plates, Analtech Inc. (visualization by staining with $\mathrm{I}_{2}$ ).

${ }^{1} \mathrm{H}$ NMR and ${ }^{13} \mathrm{C}$ NMR spectra were acquired on JEOL ECA-600 NMR-spectrometer (600 MHz for ${ }^{1} \mathrm{H}$ and $150 \mathrm{MHz}$ for ${ }^{13} \mathrm{C}$ ) with spinning at $\mathrm{rt} .{ }^{1} \mathrm{H}-{ }^{1} \mathrm{H}-\mathrm{COSY}$ and ${ }^{1} \mathrm{H}-{ }^{13} \mathrm{C}-\mathrm{HMQC}$ techniques were used to assign the signals. 1D-pfg-ROESY and 1D-pfg-STEP-NOESY experiments ${ }^{32,33}$ were carried out non-spinning at rt with selective Gauss-shaped $180^{\circ}$-pulses and with $10 \mathrm{~s}$ recovery times between pulses. After initial gradient shimming, the spinner was turned off and the shims were manually touched up for best field homogeneity. The optimal mixing time for TOCSY magnetization transfer to a specific neighboring proton was established with an arrayed experiment of 5-10 mixing times between 20-200 ms in $20 \mathrm{~ms}$ increments. The ROESY and STEP-NOESY experiments were run for 1024 scans and the raw data were zero-filled four times prior to Fourier transformation.

High resolution mass spectra (HRMS) were obtained on a JEOL AccuTOF time-of-flight mass spectrometer (Peabody, MA) coupled with an Ionsense DART open-air ionization source (Saugus, MA). The instrument was tuned to a resolving power of 7,000 with reserpine directly 
infused into the electrospray ionization source; this provides a stable ion current to tune the timeof-flight parameters. Samples were introduced into the DART sample gap with a glass melting point capillary by first dipping the closed end of the capillary into the sample then immediately placing it into the helium metastable beam. The helium gas temperature was set to $250{ }^{\circ} \mathrm{C}$ to aid in the desorption of the analyte from the capillary. The samples were held in the sample gap for 10-15 seconds to acquire several mass spectra to average for an accurate $\mathrm{m} / \mathrm{z}$ assignment.

Crystallographic Data for compounds $2 \mathbf{f}(\boldsymbol{a}), \mathbf{2 f}(\boldsymbol{e}), \mathbf{2} \mathbf{h}(\boldsymbol{e e}), 3 \mathbf{h}$ and $\mathbf{2 i}$ were collected on Beamline 11.3.1 at the Advanced Light Source, Lawrence Berkeley National Lab using monochromatic radiation $(\lambda=0.7749 \AA)$ at $150(2) \mathrm{K}$. Data reduction and cell refinement for all compounds were performed with SAINT. ${ }^{39}$ We used SADABS to obtain the absorption-corrected data. ${ }^{40}$ Crystallographic data are given in Table S1 (Supplementary data). Selected bond distances, bond angles and torsion angles are given in Tables S2-S6. CCDC $972800(\mathbf{2 f}(\boldsymbol{a}))$, $972796(\mathbf{2} \mathbf{f}(\boldsymbol{e}))$, 972799 (2h(ee) ), 972797 (3h) and 972798 (2i) contain the supplementary crystallographic data for this paper. These data can be obtained free of charge from The Cambridge Crystallographic Data Centre via www.ccdc.cam.ac.uk/data_request/cif.

\section{General procedure for epoxidation}

Alkene (5 mmol) was dissolved in dry $\mathrm{CH}_{2} \mathrm{Cl}_{2}(30 \mathrm{~mL})$, and $m$-CPBA ( $7 \mathrm{mmol} ; 70 \%$ tech. grade) was added in small portions at $0{ }^{\circ} \mathrm{C}$ while stirring. The mixture was allowed to warm to $20{ }^{\circ} \mathrm{C}$ and was stirred at r.t. for 12-48 h until complete conversion of the alkene as monitored by TLC. After addition of $\mathrm{CHCl}_{3}(30 \mathrm{~mL})$ and of satd. aqueous $\mathrm{Na}_{2} \mathrm{CO}_{3}(20 \mathrm{~mL})$, the mixture was stirred for $30 \mathrm{~min}$. Then the organic phase was separated, washed with satd. $\mathrm{Na}_{2} \mathrm{CO}_{3}(3 \times 10 \mathrm{~mL})$, dried over anhydrous $\mathrm{Na}_{2} \mathrm{SO}_{4}$, and the solvent was removed on a rotary evaporator. The purification of product was done either by column chromatography or by crystallization.

1-Methylcyclohexene 1,2-oxide (1b) was isolated by column chromatography $\left(\mathrm{Al}_{2} \mathrm{O}_{3}, \mathrm{CH}_{2} \mathrm{Cl}_{2}\right)$ as a colorless liquid (62\%). $\mathrm{R}_{f} 0.61$ (silica gel, $\left.\mathrm{CH}_{2} \mathrm{Cl}_{2}\right) .{ }^{1} \mathrm{H} \mathrm{NMR}\left(\mathrm{CDCl}_{3}\right): \delta 1.16(\mathrm{~m}, 1 \mathrm{H} ; \mathrm{H} 4)$, 1.25 (m, 1H; H5), 1.28 (s, 3H; $\mathrm{CH}_{3}$ ), 1.35-1.44 (m, 2H; H4+H5), 1.64 (ddd, $J$ 14.8, 8.1, $5.6 \mathrm{~Hz}$; $\left.\mathrm{H}^{\mathrm{ax}}\right), 1.79-1.90\left(\mathrm{~m}, 3 \mathrm{H} ; 2 \mathrm{H} 3+\mathrm{H}^{\mathrm{eq}}\right), 2.94(\mathrm{~d}, J 3.5 \mathrm{~Hz} ; \mathrm{H} 2) ;{ }^{13} \mathrm{C} \mathrm{NMR}\left(\mathrm{CDCl}_{3}\right): \delta 19.72(\mathrm{C} 4)$, 20.11 (C5), $24.06\left(\mathrm{CH}_{3}\right), 24.82$ (C3), 29.94 (C6), 57.61 (C1), 59.64 (C2) (Lit. ${ }^{41}{ }^{13} \mathrm{C}$ NMR); HRMS: $\mathrm{C}_{7} \mathrm{H}_{12} \mathrm{O}$ requires $[2 \mathrm{M}+\mathrm{H}]^{+} \mathrm{m} / z$ 225.1855, $[\mathrm{M}+\mathrm{H}]^{+} \mathrm{m} / z$ 113.0966; observed $\mathrm{m} / z$ 225.1857, 113.0961 .

3-Methyl-7-oxabicyclo[4.1.0]heptane (1c). Epoxides 1c-anti and 1c-syn were prepared in 1.3:1 ratio and were isolated by column chromatography $\left(\mathrm{Al}_{2} \mathrm{O}_{3}, \mathrm{CH}_{2} \mathrm{Cl}_{2}\right)$ as a colorless liquid (80\%). $\mathrm{R}_{f} 0.51$ (silica gel, hexane/EtOAc 9:2). Epoxide 1c-anti ${ }^{1} \mathrm{H}$ NMR $\left(\mathrm{CDCl}_{3}\right): \delta 0.83(\mathrm{~d}, J 6.8 \mathrm{~Hz}$, $\left.3 \mathrm{H} ; \mathrm{CH}_{3}\right), 0.86$ (m, 1H; H4), 1.22-1.33 (m, 1H; H3), 1.40 (m, 1H; H4), 1.69 ( dddd, $J$ 14.8, 12.5, 5.2, $1.5 \mathrm{~Hz}, \mathrm{H} 2^{\mathrm{ax}}$ ), 1.82 (ddd, $J$ 15.6, 11.4, $6.6 \mathrm{~Hz}, \mathrm{H}^{\mathrm{ax}}$ ), 1.93-2.01 (m, $\mathrm{H}^{\mathrm{eq}}$ ), 2.07-2.13 (ddd, $J$ 15.0, 4.3, $\left.2.0 \mathrm{~Hz}, \mathrm{H2}{ }^{\mathrm{eq}}\right), 3.08-3.11(\mathrm{~m}, 2 \mathrm{H} ; \mathrm{H} 1+\mathrm{H} 6) ;{ }^{13} \mathrm{C} \mathrm{NMR}\left(\mathrm{CDCl}_{3}\right): \delta 21.71\left(\mathrm{CH}_{3}\right), 23.47$ (C5), 25.26 (C4), 29.04 (C3), 33.62 (C2), 51.56, 53.23 (C1, C6) (Lit. ${ }^{42}{ }^{1} \mathrm{H}$ NMR, ${ }^{13} \mathrm{C}$ NMR for a mixture of isomers); Epoxides 1c-syn ${ }^{1} \mathrm{H}$ NMR $\left(\mathrm{CDCl}_{3}\right): \delta 0.82\left(\mathrm{~d}, J 6.6 \mathrm{~Hz}, 3 \mathrm{H} ; \mathrm{CH}_{3}\right), 1.05(\mathrm{dd}$, $J$ 14.4, 6.9 Hz, 1H; H4), 1.09 (dddd, $J$ 12.5, 4.4 Hz, H3) 1.22-1.32 (m, 1H; H4), 1.38 (dd, $J$ 15.0, 
11.7 Hz, H5 $\left.{ }^{\mathrm{ax}}\right), 1.55$ (m, 1H; H2), 1.93-2.01 (m, 1H; H5 $\left.{ }^{\mathrm{eq}}\right), 2.07-2.13(\mathrm{~m}, 1 \mathrm{H}, \mathrm{H} 2)$; 3.11-3.14 (m, 2H; H1+H6); ${ }^{13} \mathrm{C} \mathrm{NMR}\left(\mathrm{CDCl}_{3}\right): \delta 22.08\left(\mathrm{CH}_{3}\right), 24.33$ (C5), 26.47 (C4), 27.67 (C3), $32.53(\mathrm{C} 2)$, 51.95, 52.36 (C1, C6) (Lit. ${ }^{42} \mathrm{H}$ NMR, ${ }^{13} \mathrm{C}$ NMR); HRMS for the mixture: $\mathrm{C}_{7} \mathrm{H}_{12} \mathrm{O}$ requires $[2 \mathrm{M}+\mathrm{H}]^{+} \mathrm{m} / z$ 225.1855, $[\mathrm{M}+\mathrm{H}]^{+} \mathrm{m} / z$ 113.0966; observed $\mathrm{m} / z$ 225.1858, 113.0970 .

2-(7-Oxabicyclo[4.1.0]heptan-3-yl)ethanol (1d). Epoxides 1d-anti and 1d-syn were prepared in $1: 1$ ratio as a colorless liquid $(70 \%)$ and were used for further step without purification. $\mathrm{R}_{f} 0.13$ (silica gel, hexane/EtOAc 7:4). Configuration was established based on the analogy of ${ }^{1} \mathrm{H}$ NMR spectra with the other 3-substituted epoxides. Epoxide 1d-anti ${ }^{1} \mathrm{H} \mathrm{NMR}\left(\mathrm{CDCl}_{3}\right): \delta 0.91(\mathrm{~m}, 1 \mathrm{H}$; $\mathrm{H} 4), 1.29-1.50$ (m, 4H; H3+H4+CH2), 1.59 (m, 1H; H2), 1.83 (m, 1H; H5), 1.96 (m, 1H; H5), $2.13(\mathrm{~m}, 1 \mathrm{H} ; \mathrm{H} 2), 3.09-3.16(\mathrm{~m}, 2 \mathrm{H} ; \mathrm{H} 1+\mathrm{H} 6), 3.62\left(\mathrm{t}, J 6.7 \mathrm{~Hz}, 2 \mathrm{H} ; \mathrm{CH}_{2} \mathrm{O}\right) ;{ }^{13} \mathrm{C} \mathrm{NMR}\left(\mathrm{CDCl}_{3}\right)$ : $\delta 23.51$ (C5), $24.49(\mathrm{C} 4), 27.23\left(\mathrm{CH}_{2}\right), 31.87(\mathrm{C} 2), 39.14(\mathrm{C} 3), 51.96,53.11$ (C1, C6), 60.64 $\left(\mathrm{CH}_{2} \mathrm{O}\right)$; Epoxide 1d-syn ${ }^{1} \mathrm{H}$ NMR $\left(\mathrm{CDCl}_{3}\right): \delta 1.12(\mathrm{~m}, 1 \mathrm{H} ; \mathrm{H} 4), 1.30-1.49$ (m, 4H; $\left.\mathrm{H} 3+\mathrm{H} 4+\mathrm{CH}_{2}\right), 1.70$ (m, 1H; H5), 1.83 (m, 1H; H2); 2.04 (m, 1H; H5); 2.13 (m, 1H; H2), 3.09$3.16(\mathrm{~m}, 2 \mathrm{H} ; \mathrm{H} 1+\mathrm{H} 6), 3.62\left(\mathrm{t}, J 6.7 \mathrm{~Hz}, 2 \mathrm{H} ; \mathrm{CH}_{2} \mathrm{O}\right) ;{ }^{13} \mathrm{C} \mathrm{NMR}\left(\mathrm{CDCl}_{3}\right): \delta 25.24(\mathrm{C} 5), 26.34$ (C4), $29.21\left(\mathrm{CH}_{2}\right), 30.67(\mathrm{C} 2), 39.62(\mathrm{C} 3), 51.87,52.71(\mathrm{C} 1, \mathrm{C} 6), 60.34\left(\mathrm{CH}_{2} \mathrm{O}\right)$; HRMS for the mixture: $\mathrm{C}_{8} \mathrm{H}_{14} \mathrm{O}_{2}$ requires $[2 \mathrm{M}+\mathrm{H}]^{+} \mathrm{m} / \mathrm{z}$ 285.3991, $[\mathrm{M}+\mathrm{H}]^{+} \mathrm{m} / \mathrm{z}$ 143.1072; observed $\mathrm{m} / \mathrm{z}$ 285.2040, 143.1079 .

3-t-Butyl-7-oxabicyclo[4.1.0]heptanes (1e). Epoxides 1e-anti and 1e-syn were prepared in 1:2 ratio (the ratio 1:1.5 is previously described ${ }^{43}$ ) and were isolated by column chromatography $\left(\mathrm{Al}_{2} \mathrm{O}_{3}, \mathrm{CH}_{2} \mathrm{Cl}_{2}\right)$ as a colorless liquid (65\%). $\mathrm{R}_{f} 0.73$ (silica gel, $\mathrm{CH}_{2} \mathrm{Cl}_{2}$ ). Epoxide 1e-syn ${ }^{1} \mathrm{H}$ NMR $\left(\mathrm{CDCl}_{3}\right): \delta 0.78\left(\mathrm{~s}, 9 \mathrm{H} ; \mathrm{C}\left(\mathrm{CH}_{3}\right)_{3}\right), 0.97(\mathrm{dtd}, J$ 2.1, 12.2, $5.9 \mathrm{~Hz}, \mathrm{H} 4 \mathrm{ax}), 1.06(\mathrm{dq}, J$ 4.1, $12.6 \mathrm{~Hz}, \mathrm{H} 3$ ), 1.36 (m, H4 ${ }^{\mathrm{eq}}$ ), 1.57 (dd, $J 12.1,15.2 \mathrm{~Hz}, \mathrm{H} 5^{\mathrm{ax}}$ ), 1.65 (dddd, $J 1.5,4.8,12.5,14.6$ $\left.\mathrm{Hz}, \mathrm{H} 2^{\mathrm{ax}}\right), 1.95$ (dtd, J 2.2, 5.8, $\left.15.3 \mathrm{~Hz}, \mathrm{H} 5^{\mathrm{eq}}\right), 2.16\left(\mathrm{~m}, \mathrm{H} 2^{\mathrm{eq}}\right), 3.11(\mathrm{~m}, \mathrm{H} 1), 3.14(\mathrm{dd}, J 5.5,3.9$ $\mathrm{Hz}, \mathrm{H} 6)$; Epoxide 1e-anti ${ }^{1} \mathrm{H}$ NMR $\left(\mathrm{CDCl}_{3}\right): \delta 0.80\left(\mathrm{~s}, 9 \mathrm{H} ; \mathrm{C}\left(\mathrm{CH}_{3}\right)_{3}\right), 0.85(\mathrm{~m}, 1 \mathrm{H} ; \mathrm{H} 4), 1.21$ (dtd, $J$ 2.0, 12.1, 3.9 Hz, H3), 1.37 (m, 1H; H4), 1.50 (m, 1H; H2), 1.75 (ddd, J 15.4, 12.9, 6.3 $\mathrm{Hz}, \mathrm{H}^{\mathrm{ax}}$ ), 2.04 (dtd, J 15.5, 5.9, $\left.1.7 \mathrm{~Hz}, \mathrm{H}^{\mathrm{eq}}\right), 2.16$ (m, 1H; H2), 3.11 (m, 1H; H6), 3.21 (m, 1H; H1).

Methyl 7-oxabicyclo[4.1.0]heptane-3-carboxylates (1f). Epoxides 1f-anti and 1f-syn were prepared in 2:1 ratio (the same ratio as described previously ${ }^{44}$ ) and were separated by column chromatography $\left(\mathrm{Al}_{2} \mathrm{O}_{3}, \mathrm{CH}_{2} \mathrm{Cl}_{2}\right)$. Epoxide 1f-anti is a colorless liquid (51\%). $\mathrm{R}_{f} 0.68\left(\mathrm{Al}_{2} \mathrm{O}_{3}\right.$, $\left.\mathrm{CH}_{2} \mathrm{Cl}_{2}\right) .{ }^{1} \mathrm{H}$ NMR $\left(\mathrm{CDCl}_{3}\right): \delta 1.39$ (ddt, $\left.J 13.4,10.1,6.5 \mathrm{~Hz}, \mathrm{H} 4{ }^{\mathrm{ax}}\right), 1.74\left(\mathrm{~m}, \mathrm{H} 4^{\mathrm{eq}}\right), 1.85-1.99$ $\left(\mathrm{m}, 3 \mathrm{H} ; 2 \mathrm{H} 5+\mathrm{H} 2^{\mathrm{ax}}\right), 2.25\left(\mathrm{dd}, J 15.0,4.9 \mathrm{~Hz}, \mathrm{H} 2^{\mathrm{eq}}\right), 2.50$ (ddd, $\left.J 9.5,4.9,3.0 \mathrm{~Hz}, \mathrm{H} 3\right), 3.12$ (t, $J$ $4.0 \mathrm{~Hz}, \mathrm{H} 6), 3.21(\mathrm{~m}, \mathrm{H} 1), 3.65\left(\mathrm{~s}, 3 \mathrm{H} ; \mathrm{OCH}_{3}\right) ;{ }^{13} \mathrm{C} \mathrm{NMR}\left(\mathrm{CDCl}_{3}\right): \delta 22.84,22.96(\mathrm{C} 4, \mathrm{C} 5)$, $27.23(\mathrm{C} 2), 35.79$ (C3), 51.46, 51.81, $52.28\left(\mathrm{C} 1, \mathrm{C} 6, \mathrm{CH}_{3}\right), 175.98(\mathrm{C}=\mathrm{O})$; HRMS: $\mathrm{C}_{8} \mathrm{H}_{12} \mathrm{O}_{3}$ requires $[2 \mathrm{M}+\mathrm{H}]^{+} \mathrm{m} / \mathrm{z}$ 313.1651, $[\mathrm{M}+\mathrm{H}]^{+} \mathrm{m} / \mathrm{z}$ 157.0865; observed $\mathrm{m} / \mathrm{z}$ 313.1675, 157.0898 . Epoxide 1f-syn is a colorless liquid $(25 \%) . \mathrm{R}_{f} 0.63\left(\mathrm{Al}_{2} \mathrm{O}_{3}, \mathrm{CH}_{2} \mathrm{Cl}_{2}\right) .{ }^{1} \mathrm{H} \mathrm{NMR}\left(\mathrm{CDCl}_{3}\right): \delta 1.52$ $1.64(\mathrm{~m}, 2 \mathrm{H} 4), 1.75$ (dddd, $\left.J 15.0,11.1,5.6,1.7 \mathrm{~Hz}, \mathrm{H} 5^{\mathrm{ax}}\right), 2.08-2.27\left(\mathrm{~m}, 4 \mathrm{H} ; 2 \mathrm{H} 2+\mathrm{H} 3+\mathrm{H} 5^{\mathrm{eq}}\right.$ ), 3.12-3.16 (m, 2H; H1+H6), $3.65\left(\mathrm{~s}, 3 \mathrm{H} ; \mathrm{OCH}_{3}\right) ;{ }^{13} \mathrm{C} \mathrm{NMR}\left(\mathrm{CDCl}_{3}\right): \delta 21.11(\mathrm{C} 4), 24.11(\mathrm{C} 5)$, $26.33(\mathrm{C} 2), 37.89(\mathrm{C} 3), 50.76,51.81\left(\mathrm{C} 1, \mathrm{C} 6, \mathrm{CH}_{3}\right), 175.33(\mathrm{C}=\mathrm{O})$; HRMS: $\mathrm{C}_{8} \mathrm{H}_{12} \mathrm{O}_{3}$ requires $[2 \mathrm{M}+\mathrm{H}]^{+} \mathrm{m} / z$ 313.1651, $[\mathrm{M}+\mathrm{H}]^{+} \mathrm{m} / \mathrm{z}$ 157.0865; observed $\mathrm{m} / \mathrm{z} 313.1675,157.0898$. 
Diethyl 7-oxabicyclo[4.1.0]heptane-trans-3,4-dicarboxylate (1g) was prepared as described ${ }^{45}$ and isolated by column chromatography $\left(\mathrm{Al}_{2} \mathrm{O}_{3}\right.$, hexane/EtOAc gradient washing 8:2 $\left.\rightarrow 7: 3\right)$ as a colorless liquid (60\%). $\mathrm{R}_{f} 0.74\left(\mathrm{Al}_{2} \mathrm{O}_{3}\right.$, hexane/EtOAc 7:3). ${ }^{1} \mathrm{H} \mathrm{NMR}\left(\mathrm{CDCl}_{3}\right): \delta 1.21$ (t, $J 7.1$ $\mathrm{Hz}, 3 \mathrm{H} ; \mathrm{CH}_{3}$ ), 1.22 (t, J 7.1 Hz, 3H; $\mathrm{CH}_{3}$ ), 1.87 (ddd, J 14.9, 10.8, $2.1 \mathrm{~Hz}, \mathrm{H} 2^{\mathrm{ax}}$ ), 2.04 (dd, $J$ $\left.15.5,10.9 \mathrm{~Hz}, \mathrm{H} 5^{\mathrm{ax}}\right), 2.30\left(\mathrm{ddd}, J 15.5,6.6,4.8 \mathrm{~Hz}, \mathrm{H} 5^{\mathrm{eq}}\right), 2.45\left(\mathrm{ddd}, J 14.9,4.8,1.8 \mathrm{~Hz}, \mathrm{H} 2^{\mathrm{eq}}\right.$ ), 2.58 (dt, $J$ 10.7, 6.7 Hz, H4), 2.80 (dt, J 10.7, 4.9 Hz, H3), 3.17 (t, J 4.3 Hz, H6), 3.24 (m, H1), $4.11\left(\mathrm{~m}, 4 \mathrm{H}, \mathrm{OCH}_{2}\right) ;{ }^{13} \mathrm{C} \mathrm{NMR}\left(\mathrm{CDCl}_{3}\right): \delta 14.20\left(\mathrm{CH}_{3}\right), 26.44(\mathrm{C} 5), 27.30(\mathrm{C} 2), 37.80(\mathrm{C} 3)$, 40.14 (C4), 50.40 (C6), $52.00(\mathrm{C} 1), 60.84\left(\mathrm{OCH}_{2}\right), 173.76,174.82(\mathrm{C}=\mathrm{O})$; HRMS: $\mathrm{C}_{12} \mathrm{H}_{18} \mathrm{O}_{5}$ requires $[\mathrm{M}+\mathrm{H}]^{+} \mathrm{m} / \mathrm{z} 243.1233$; observed $\mathrm{m} / \mathrm{z} 243.1240$.

Dimethyl 7-oxabicyclo[4.1.0]heptane-cis-3,4-dicarboxylates (1h). Epoxides $1 \mathrm{~h}-$ anti and $1 \mathrm{~h}-$ $\boldsymbol{s y n}$ were prepared according to the synthetic procedure reported previously. ${ }^{45}$ Epoxide $\mathbf{1 h}$-anti is a colorless liquid. ${ }^{1} \mathrm{H}$ NMR $\left(\mathrm{CDCl}_{3}\right): \delta 2.17-2.29(\mathrm{~m}, 4 \mathrm{H} ; 2 \mathrm{H} 2+2 \mathrm{H} 5), 2.88-2.92(\mathrm{~m}, 2 \mathrm{H}$; $\mathrm{H} 3+\mathrm{H} 4), 3.20-3.23(\mathrm{~m}, 2 \mathrm{H} ; \mathrm{H} 1+\mathrm{H} 6), 3.67\left(\mathrm{~s}, 6 \mathrm{H} ; \mathrm{OCH}_{3}\right) ;{ }^{13} \mathrm{C} \mathrm{NMR}\left(\mathrm{CDCl}_{3}\right): \delta 24.79(\mathrm{C} 2, \mathrm{C} 5)$, $37.69(\mathrm{C} 3, \mathrm{C} 4), 51.61(\mathrm{C} 1, \mathrm{C} 6), 52.12\left(\mathrm{OCH}_{3}\right), 173.56(\mathrm{C}=\mathrm{O})$. Epoxide 1h-syn is a colorless liquid. ${ }^{1} \mathrm{H}$ NMR $\left(\mathrm{CDCl}_{3}\right): \delta 2.08-2.14(\mathrm{~m}, 2 \mathrm{H} ; \mathrm{H} 2+\mathrm{H} 5), 2.63-2.68(\mathrm{~m}, 2 \mathrm{H} ; \mathrm{H} 2+\mathrm{H} 5)$ 2.71-2.75 $(\mathrm{m}, 2 \mathrm{H} ; \mathrm{H} 3+\mathrm{H} 4), 3.14-3.16(\mathrm{~m}, 2 \mathrm{H} ; \mathrm{H} 1+\mathrm{H} 6), 3.66\left(\mathrm{~s}, 6 \mathrm{H} ; \mathrm{OCH}_{3}\right) ;{ }^{13} \mathrm{C} \mathrm{NMR}\left(\mathrm{CDCl}_{3}\right): \delta 24.82$ $(\mathrm{C} 2, \mathrm{C} 5), 37.57(\mathrm{C} 3, \mathrm{C} 4), 51.03(\mathrm{C} 1, \mathrm{C} 6), 51.97\left(\mathrm{OCH}_{3}\right), 173.09(\mathrm{C}=\mathrm{O})$. The configurations were assigned according to ${ }^{1} \mathrm{H}$ and ${ }^{13} \mathrm{C}$ NMR data previously reported. ${ }^{45}$

7-Oxabicyclo[4.1.0]heptane-cis-3,4-dicarboxylic acid imides (1i). Epoxides 1i-anti and 1i-syn were prepared in 1:5.5 ratio. Configuration of the major 1i-syn epoxide was established based on $\mathrm{NOE}$ analysis of the product 4 of epoxide cleavage with $\mathrm{MeOH} / \mathrm{H}^{+}$(see Supplementary data). Epoxide 1i-syn was isolated by recrystallization from $\mathrm{MeOH}$ as a white solid (84\%). Mp 225$229{ }^{\circ} \mathrm{C} ; \mathrm{R}_{f} 0.55\left(\mathrm{Al}_{2} \mathrm{O}_{3}, \mathrm{CHCl}_{3} / \mathrm{MeOH} 10: 1\right) .{ }^{1} \mathrm{H}$ NMR $\left(\mathrm{CD}_{3} \mathrm{OD}\right): \delta 2.16-2.22(\mathrm{~m}, 2 \mathrm{H} ; \mathrm{H} 2+\mathrm{H} 5)$, 2.51-2.57 (m, 2H; H2+H5), 2.79-2.82 (m, 2H; H3+H4), 3.13-3.16 (m, 2H; H1+H6); ${ }^{13} \mathrm{C}$ NMR $\left(\mathrm{CD}_{3} \mathrm{OD}\right): \delta 21.63(\mathrm{C} 2, \mathrm{C} 5), 36.51(\mathrm{C} 3, \mathrm{C} 4), 50.79(\mathrm{C} 1, \mathrm{C} 6), 183.11(\mathrm{C}=\mathrm{O})$; HRMS: $\mathrm{C}_{8} \mathrm{H}_{9} \mathrm{NO}_{3}$ requires $[2 \mathrm{M}+\mathrm{H}]^{+} \mathrm{m} / \mathrm{z}$ 335.1243, $[\mathrm{M}+\mathrm{H}]^{+} \mathrm{m} / \mathrm{z}$ 168.0661; observed $\mathrm{m} / \mathrm{z}$ 335.1226, 168.0681 . Epoxide 1i-anti was characterized by NMR in the mixture with the major epoxide. ${ }^{1} \mathrm{H}$ NMR (CD $\left.{ }_{3} \mathrm{OD}\right): \delta$ 1.94-2.00 (m, 2H; H2+H5), 2.42-2.48 (m, 2H; H2+H5), 2.87-2.93 (m, 2H; H3+H4), 3.20-3.22 (m, 2H; H1+H6); ${ }^{13} \mathrm{C}$ NMR (CD $\left.\mathrm{OD}\right): \delta 22.56(\mathrm{C} 2, \mathrm{C} 5), 36.56(\mathrm{C} 3, \mathrm{C} 4), 49.08(\mathrm{C} 1$, C6), $182.84(\mathrm{C}=\mathrm{O})$.

1,2-Anhydro-3,4,6-tri- $O$-benzyl- $\alpha$-D-glucopyranose (1k). Tri- $O$-benzyl-glucal $(0.53 \mathrm{~g}, 1.27$ mmol) was dissolved in the mixture of $\mathrm{CH}_{2} \mathrm{Cl}_{2}(5 \mathrm{~mL})$, acetone $(1 \mathrm{~mL})$ and satd $\mathrm{NaHCO}_{3}(10$ $\mathrm{mL})$. A solution of Oxone $(1.6 \mathrm{~g}, 2.6 \mathrm{mmol})$ in $\mathrm{H}_{2} \mathrm{O}(6 \mathrm{~mL})$ was added dropwise over $15 \mathrm{~min}$ at $0{ }^{\circ} \mathrm{C}$ while stirring. The mixture was allowed to warm up to room temperature and was stirred for 16h. The organic phase was separated and the aqueous phase was extracted with $\mathrm{CH}_{2} \mathrm{Cl}_{2}(2 \times 20$ $\mathrm{mL}$ ). The combined organic phases were dried over $\mathrm{Na}_{2} \mathrm{SO}_{4}$ and concentrated under vacuum. The pure product was obtained by crystallization from $\mathrm{MeOH}$ as a white solid $(0.40 \mathrm{~g}, 73 \%) .{ }^{1} \mathrm{H}$ NMR $\left(\mathrm{CDCl}_{3}\right.$ ): $\delta 3.06$ (d, J 2.2 Hz, H2), 3.66-3.75 (m, 4H; H4+H5+2H6), 3.97 (d, J 7.8 Hz, H3), $4.53\left(\mathrm{~d}, J 12.1 \mathrm{~Hz}, 1 \mathrm{H} ; \mathrm{CH}_{2}\right.$, benzyl), 4.58 (d, J $11.0 \mathrm{~Hz}, 1 \mathrm{H} ; \mathrm{CH}_{2}$, benzyl), 4.62 (d, J $12.0 \mathrm{~Hz}$, $1 \mathrm{H} ; \mathrm{CH}_{2}$, benzyl), 4.69 (d, J $11.5 \mathrm{~Hz}, 1 \mathrm{H} ; \mathrm{CH}_{2}$, benzyl), 4.81 (d, J11.3 Hz, 2H; $\mathrm{CH}_{2}$, benzyl), 
4.99 (d, J 1.4 Hz, H1), 7.15-7.19 (m, 2H, aromatic), 7.25-7.38 (m, 13H, aromatic) (Lit. ${ }^{46,47 ~}{ }^{1} \mathrm{H}$ NMR data). HRMS: $\mathrm{C}_{27} \mathrm{H}_{28} \mathrm{O}_{5}$ requires $[2 \mathrm{M}+\mathrm{H}]^{+} m / z$ 865.3952, $[\mathrm{M}+\mathrm{H}]^{+} m / z$ 433.2015; observed $\mathrm{m} / z$ 865.3988, 433.2002.

Ethyl 4,6-di- $\boldsymbol{O}$-acetyl-2,3-anhydro-a-D-manno- (11) and allo-hexopyranosides were prepared according to the procedure previously reported. ${ }^{48}$ The diastereomeric epoxides were obtained in the ratio 10:1 (manno:allo) with the overall yield 45\%. Manno-hexopyranoside (11): was isolated by column chromatography, (silica gel, hexane/EtOAc gradient washing 5:1 $\rightarrow 5: 2$ ) as a colorless syrup. ${ }^{1} \mathrm{H} \mathrm{NMR}\left(\mathrm{CDCl}_{3}\right): \delta 1.26\left(\mathrm{t}, J 7.1 \mathrm{~Hz}, 3 \mathrm{H} ; \mathrm{CH}_{3}\right.$, ethyl), $2.06\left(\mathrm{~s}, 3 \mathrm{H} ; \mathrm{CH}_{3}\right.$, acetyl), 2.11 (s, $3 \mathrm{H} ; \mathrm{CH}_{3}$, acetyl), 3.08 (d, J 3.5 Hz, H3), 3.21 (d, J 3.5 Hz, H2), 3.60 (dq, J 9.7, 7.1 Hz, 1H; $\mathrm{CH}_{2}$, ethyl), 3.83 (dq, $J 9.7,7.1 \mathrm{~Hz}, 1 \mathrm{H}$; $\mathrm{CH}_{2}$, ethyl), 3.90 (ddd, $J$ 9.8, 5.5, $2.8 \mathrm{~Hz}, \mathrm{H} 5$ ), 4.10 (m, 2H6), $4.86(\mathrm{~d}, J 10.0 \mathrm{~Hz}, \mathrm{H} 4), 5.00(\mathrm{~s}, \mathrm{H} 1)\left(\mathrm{Lit}^{48}{ }^{1} \mathrm{H} \mathrm{NMR}\right.$ data); ${ }^{13} \mathrm{C} \mathrm{NMR}\left(\mathrm{CDCl}_{3}\right): \delta 15.12\left(\mathrm{CH}_{3}\right.$, ethyl), $20.84\left(\mathrm{CH}_{3}\right.$, acetyl), $20.90\left(\mathrm{CH}_{3}\right.$, acetyl), 49.38(C3), 53.34 (C2), 63.13 (C4 and $\left.\mathrm{C} 6\right), 64.24$ $\left(\mathrm{CH}_{2}\right.$, ethyl), $64.73(\mathrm{C} 5), 94.89(\mathrm{C} 1), 169.69(\mathrm{C}=\mathrm{O}), 170.82(\mathrm{C}=\mathrm{O})$; HRMS: $\mathrm{C}_{12} \mathrm{H}_{18} \mathrm{O}_{7}$ requires $\left[\mathrm{C}_{10} \mathrm{H}_{13} \mathrm{O}_{6}\right]^{+} \mathrm{m} / \mathrm{z}$ 229.0712; observed $\mathrm{m} / \mathrm{z}$ 229.0722. The configuration of epoxide 11 was confirmed by NOE analysis (see Supplementary data). Allo-hexopyranoside was characterized by ${ }^{1} \mathrm{H}$ NMR in mixture with the major stereoisomer. ${ }^{1} \mathrm{H} \mathrm{NMR}\left(\mathrm{CDCl}_{3}\right): \delta 1.24(\mathrm{t}, J 7.2 \mathrm{~Hz}, 3 \mathrm{H}$; $\mathrm{CH}_{3}$, ethyl), 2.08 (s, 3H; $\mathrm{CH}_{3}$, acetyl), 2.11 (s, 3H; $\mathrm{CH}_{3}$, acetyl), 3.53 (dd, J 4.2, $3.0 \mathrm{~Hz}, \mathrm{H} 2$ ), 3.55 (dd, $J 4.1,1.6 \mathrm{~Hz}, \mathrm{H} 3$ ), 3.60 (dq, $J 9.8,7.1 \mathrm{~Hz}, 1 \mathrm{H} ; \mathrm{CH}_{2}$, ethyl), 3.81 (dq, $J$ 9.8, $7.1 \mathrm{~Hz}, 1 \mathrm{H}$; $\mathrm{CH}_{2}$, ethyl), 4.10 (m, 2H6), 4.20 (dd, $\left.J 12.4,5.1 \mathrm{~Hz}, \mathrm{H} 5\right), 5.04$ (d, $J 3.0 \mathrm{~Hz}, \mathrm{H} 1$ ), 5.00 (dd, $J 10.0$, $1.5 \mathrm{~Hz}, \mathrm{H} 4)$ (Lit. ${ }^{48}{ }^{1} \mathrm{H}$ NMR data).

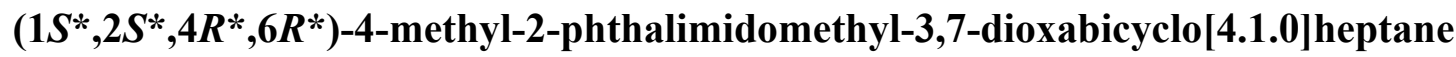

(1m). Synthesis of this compound was reported previously. ${ }^{49,50}{ }^{1} \mathrm{H} \mathrm{NMR}\left(\mathrm{CDCl}_{3}\right): \delta 1.08(\mathrm{~d}, J 6.2 \mathrm{~Hz}$, $3 \mathrm{H} ; \mathrm{CH}_{3}$ ), 1.62 (ddd, $J$ 14.6, 11.0, $1.8 \mathrm{~Hz}, \mathrm{H} 5^{\mathrm{ax}}$ ), 2.01 (dt, $J 14.6,2.2 \mathrm{~Hz}, \mathrm{H} 5^{\mathrm{eq}}$ ), 3.16 (d, $J 4.3$ Hz, H1), 3.33 (dt, J 4.2, 1.8 Hz, H6), 3.47 (m, J 6.2, 2.6 Hz, H4), 3.92 (m, 2H; $\left.\mathrm{CH}_{2} \mathrm{~N}\right), 4.10$ (t, $J$ $7.02 \mathrm{~Hz}, \mathrm{H} 2), 7.72\left(\mathrm{~m}, 2 \mathrm{H}\right.$, aromatic), $7.86\left(\mathrm{~m}, 2 \mathrm{H}\right.$, aromatic); ${ }^{13} \mathrm{C} \mathrm{NMR}\left(\mathrm{CDCl}_{3}\right): \delta 21.08\left(\mathrm{CH}_{3}\right)$, 32.82 (C5), $40.11\left(\mathrm{CH}_{2} \mathrm{~N}\right), 51.68(\mathrm{C} 6), 52.36(\mathrm{C} 1), 65.95(\mathrm{C} 4), 72.41(\mathrm{C} 2), 123.53,132.03$, 134.22 (C, aromatic), $168.35(\mathrm{C}=\mathrm{O})$. HRMS: $\mathrm{C}_{15} \mathrm{H}_{15} \mathrm{NO}_{4}$ requires $[\mathrm{M}+\mathrm{H}]^{+} \mathrm{m} / z$ 274.1079; observed $m / z 274.1072$.

General procedure for the synthesis of trithiocarbonates. Potassium ethyl xanthogenate (2 mmol) was dissolved in $\mathrm{MeOH}(3 \mathrm{~mL})$ under Ar atmosphere and a solution of epoxide (1 mmol) in $\mathrm{MeOH}(2 \mathrm{~mL})$ was added at $35-45{ }^{\circ} \mathrm{C}$ while stirring. The mixture was stirred at this temperature until the complete conversion of the epoxide, as monitored by TLC (the time of reaction is shown in Table 2). The solvent was removed on a rotary evaporator. The purification of product was done either by column chromatography or by crystallization.

Hexahydro-1,3-benzodithiole-2-thione (2a) was prepared from cyclohexene epoxide 1a and was isolated by column chromatography (silica gel, $\mathrm{CHCl}_{3} /$ hexane 9:2) as a yellow solid (73\%). Mp 167-169 ${ }^{\circ} \mathrm{C}$, (Lit. ${ }^{2,34} \mathrm{Mp} 164-169{ }^{\circ} \mathrm{C}$ ); $\mathrm{R}_{f} 0.54$ (silica gel, $\mathrm{CHCl}_{3} /$ hexane 9:2). ${ }^{1} \mathrm{H} \mathrm{NMR}$ $\left(\mathrm{CDCl}_{3}\right): \delta 1.42-1.50\left(\mathrm{~m}, 2 \mathrm{H} ; \mathrm{H}^{\mathrm{ax}}+\mathrm{H}^{\mathrm{ax}}\right), 1.67-1.77\left(\mathrm{~m}, 2 \mathrm{H} ; \mathrm{H}^{\mathrm{ax}}+\mathrm{H} 7^{\mathrm{ax}}\right), 1.91-1.99(\mathrm{~m}, 2 \mathrm{H}$; $\left.\mathrm{H}^{\mathrm{eq}}+\mathrm{H} 6^{\mathrm{eq}}\right), 2.18-2.23\left(\mathrm{~m}, 2 \mathrm{H} ; \mathrm{H} 4^{\mathrm{eq}}+\mathrm{H} 7^{\mathrm{eq}}\right), 4.05-4.11(\mathrm{~m}, 2 \mathrm{H} ; \mathrm{H} 3 \mathrm{a}+\mathrm{H} 7 \mathrm{a}) ;{ }^{13} \mathrm{C} \mathrm{NMR}\left(\mathrm{CDCl}_{3}\right): \delta$ 
25.13 (C5, C6), 29.17(C4, C7), 64.59 (C3a, C7a), 227.21 (C=S), (Lit. ${ }^{2}{ }^{1} \mathrm{H}$ NMR, ${ }^{13} \mathrm{C}$ NMR); HRMS: $\mathrm{C}_{7} \mathrm{H}_{10} \mathrm{~S}_{3}$ requires $[\mathrm{M}+\mathrm{H}]^{+} \mathrm{m} / z$ 191.0023; observed $\mathrm{m} / z$ 191.0040.

3a-Methyl-hexahydro-1,3-benzodithiole-2-thione (2b) was prepared from epoxide $\mathbf{1 b}$ and was isolated by column chromatography (silica gel, $\mathrm{CH}_{2} \mathrm{Cl}_{2}$ ) as a yellow oil (37\%). $\mathrm{R}_{f} 0.49$ (silica gel, $\left.\mathrm{CH}_{2} \mathrm{Cl}_{2}\right)$. ${ }^{1} \mathrm{H}$ NMR $\left(\mathrm{CDCl}_{3}\right): \delta 1.48\left(\mathrm{~m}, \mathrm{H}^{\mathrm{ax}}\right), 1.62\left(\mathrm{~m}, \mathrm{H}^{\mathrm{ax}}\right), 1.68\left(\mathrm{~s}, 3 \mathrm{H} ; \mathrm{CH}_{3}\right), 1.71-1.79$ $\left(\mathrm{m}, 2 \mathrm{H} ; \mathrm{H}^{\mathrm{eq}}+\mathrm{H}^{\mathrm{ax}}\right), 1.93-1.98\left(\mathrm{~m}, 2 \mathrm{H} ; \mathrm{H}^{\mathrm{eq}}+\mathrm{H} 7^{\mathrm{eq}}\right), 2.01\left(\mathrm{dt}, J 4.3,13.0 \mathrm{~Hz}, \mathrm{H} 4^{\mathrm{ax}}\right) ; 2.13(\mathrm{dddd}, J$ 12.8, 3.9, 2.7, $\left.1.1 \mathrm{~Hz}, \mathrm{H} 4{ }^{\mathrm{eq}}\right), 4.41(\mathrm{dd}, J 13.1,3.4 \mathrm{~Hz}, \mathrm{H} 7 \mathrm{a}) ;{ }^{13} \mathrm{C} \mathrm{NMR}\left(\mathrm{CDCl}_{3}\right): \delta 18.91\left(\mathrm{CH}_{3}\right)$, 20.83 (C5), 23.78 (C7), 25.37 (C6), 35.69 (C4), 67.99 (C3a, C7a), 226.69 (C=S); HRMS: $\mathrm{C}_{8} \mathrm{H}_{12} \mathrm{~S}_{3}$ requires $[\mathrm{M}+\mathrm{H}]^{+} \mathrm{m} / \mathrm{z} 205.0179$; observed $\mathrm{m} / \mathrm{z} 205.0173$.

$\left(1 S^{*}, 2 S^{*}, 5 R^{*}\right)$-5-Methylhexahydro-1,3-benzodithiole-2-thione (2c) was prepared from epoxide 1c and was isolated by column chromatography (silica gel, $\mathrm{CH}_{2} \mathrm{Cl}_{2} /$ hexane 10:3) as a yellow solid (37\%). Mp 123-125 ${ }^{\circ} \mathrm{C}$; $\mathrm{R}_{f} 0.62$ (silica gel, $\mathrm{CH}_{2} \mathrm{Cl}_{2} /$ hexane 10:3). ${ }^{1} \mathrm{H}$ NMR $\left(\mathrm{CDCl}_{3}\right): \delta 1.09$ (d, J 7.4 Hz, 3H; $\left.\mathrm{CH}_{3}\right), 1.68-1.72$ (m, 2H6), 1.86-2.03 (m, 4H; 2H4+2H7), 2.25 (m, H5), 4.03 (dt, $J 12.2,3.7 \mathrm{~Hz}, \mathrm{H} 7 \mathrm{a}), 4.32(\mathrm{dt}, J 12.2,4.1 \mathrm{~Hz}, \mathrm{H} 3 \mathrm{a}) ;{ }^{13} \mathrm{C} \mathrm{NMR}\left(\mathrm{CDCl}_{3}\right): \delta$ $17.98\left(\mathrm{CH}_{3}\right), 23.98$ (C7), 27.20 (C5), 30.51 (C6), 34.40(C4), 59.79 (C3a), 65.01 (C7a), 227.14 $(\mathrm{C}=\mathrm{S})$; HRMS: $\mathrm{C}_{8} \mathrm{H}_{12} \mathrm{~S}_{3}$ requires $[\mathrm{M}+\mathrm{H}]^{+} \mathrm{m} / \mathrm{z}$ 205.0179; observed $\mathrm{m} / \mathrm{z} 205.0125$.

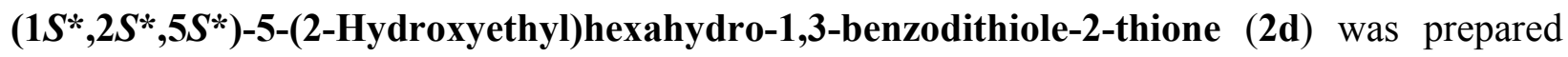
from epoxide 1d and was isolated by column chromatography (silica gel, $\mathrm{CH}_{2} \mathrm{Cl}_{2} / \mathrm{MeOH}$ 10:0.5) as a yellow oil (59\%). $\mathrm{R}_{f} 0.56$ (silica gel, $\left.\mathrm{CH}_{2} \mathrm{Cl}_{2} / \mathrm{MeOH} 10: 0.5\right) .{ }^{1} \mathrm{H} \mathrm{NMR}\left(\mathrm{CDCl}_{3}\right): \delta 1.66-1.77$ (m, 3H; $\left.\mathrm{CH}_{2}+\mathrm{H} 6\right), 1.81-1.88\left(\mathrm{~m}, 2 \mathrm{H} ; \mathrm{H} 6+\mathrm{H}^{\mathrm{ax}}\right), 1.93$ (dt, $\left.J 13.0,4.7 \mathrm{~Hz}, \mathrm{H} 4^{\mathrm{ax}}\right), 2.05$ (dq, $J 13.5$, $3.6 \mathrm{~Hz}, \mathrm{H}^{\mathrm{eq}}$ ), 2.10 (m, H4eq), 2.22 (m, H5), 3.71 (dt, J 6.4, 2.2 Hz, 2H; $\mathrm{CH}_{2} \mathrm{O}$ ), 4.06 (dt, $J$ 12.1, $3.7 \mathrm{~Hz}, \mathrm{H} 7 \mathrm{a}), 4.27$ (dt, $J 12.6,3.5 \mathrm{~Hz}, \mathrm{H} 3 \mathrm{a}) ;{ }^{13} \mathrm{C} \mathrm{NMR}\left(\mathrm{CDCl}_{3}\right): \delta 24.50(\mathrm{C} 7), 28.91(\mathrm{C} 6), 29.34$ (C5), $32.85(\mathrm{C} 4), 34.21\left(\mathrm{CH}_{2}\right), 60.18(\mathrm{C} 3 \mathrm{a}), 61.03\left(\mathrm{CH}_{2} \mathrm{OH}\right), 64.92(\mathrm{C} 7 \mathrm{a}), 227.00(\mathrm{C}=\mathrm{S})$; HRMS: $\mathrm{C}_{9} \mathrm{H}_{14} \mathrm{OS}_{3}$ requires $[\mathrm{M}+\mathrm{H}]^{+} m / z$ 235.0285; observed $m / z 235.0273$.

5-(Methoxycarbonyl)hexahydro-1,3-benzodithiole-2-thiones $\quad[2 f(a)$ and $2 \mathrm{f}(e)]$ were synthesized from individual 1f-anti and 1f-syn epoxides or from their mixture with overall yields $50-60 \%$. The ratio of diastereomers was dependent on the time of the reaction: after $0.5 \mathrm{~h}$ the ratio of products $\mathbf{2 f}(\boldsymbol{a}): \mathbf{2 f}(\boldsymbol{e})$ was (2.2-3.3):1; after 2-3 h the ratio was 1:1.3.

$\left(1 S^{*}, 2 S^{*}, 5 R^{*}\right)-5$-(Methoxycarbonyl)-hexahydro-1,3-benzodithiole-2-thione $\quad[2 \mathrm{f}(a)]$ was isolated by column chromatography (silica gel, $\mathrm{CH}_{2} \mathrm{Cl}_{2}$ /hexane 10:3) as a yellow solid. Mp 95-97 ${ }^{\circ} \mathrm{C} ; \mathrm{R}_{f} 0.39$ (silica gel, $\mathrm{CH}_{2} \mathrm{Cl}_{2} /$ hexane 10:3). ${ }^{1} \mathrm{H}$ NMR $\left(\mathrm{CDCl}_{3}\right): \delta 1.69$ (dddd, $J$ 14.2, 13.5, 5.3, $\left.4.0 \mathrm{~Hz}, \mathrm{H}^{\mathrm{ax}}\right), 1.88\left(\mathrm{dq}, J 3.6,13.1 \mathrm{~Hz}, \mathrm{H}^{\mathrm{ax}}\right), 1.92\left(\mathrm{dq}, J 12.9,5.0 \mathrm{~Hz}, \mathrm{H}^{\mathrm{ax}}\right), 2.12(\mathrm{dq}, J 13.3$, $3.5 \mathrm{~Hz}, \mathrm{H}^{\mathrm{eq}}$ ), $2.41\left(\mathrm{~m}, \mathrm{H}^{\mathrm{eq}}\right), 2.64\left(\mathrm{ddd}, J 13.3,3.6,2.1 \mathrm{~Hz}, \mathrm{H}^{\mathrm{eq}}\right), 2.94$ (tt, $J \approx 2.5,5.0 \mathrm{~Hz}, \mathrm{H} 5$ ), $3.74\left(\mathrm{~s}, 3 \mathrm{H} ; \mathrm{OCH}_{3}\right), 4.07(\mathrm{dt}, J 12.2,3.6 \mathrm{~Hz}, \mathrm{H} 7 \mathrm{a}), 4.29(\mathrm{dt}, J 12.4,3.5 \mathrm{~Hz}, \mathrm{H} 3 \mathrm{a}) ;{ }^{13} \mathrm{C}$ NMR $\left(\mathrm{CDCl}_{3}\right): \delta 25.90,26.44(\mathrm{C} 6, \mathrm{C} 7), 29.89(\mathrm{C} 4), 38.55(\mathrm{C} 5), 52.27\left(\mathrm{OCH}_{3}\right), 60.55(\mathrm{C} 3 \mathrm{a}), 63.88$ (C7a), $173.67(\mathrm{C}=\mathrm{O}), 226.03(\mathrm{C}=\mathrm{S})$; HRMS: $\mathrm{C}_{9} \mathrm{H}_{12} \mathrm{O}_{2} \mathrm{~S}_{3}$ requires $[\mathrm{M}+\mathrm{H}]^{+} \mathrm{m} / z$ 249.0078; observed $m / z 249.0074$.

$\left(1 S^{*}, 2 S^{*}, 5 S^{*}\right)-5-(M e t h o x y c a r b o n y l) h e x a h y d r o-1,3-b e n z o d i t h i o l e-2-t h i o n e \quad[2 \mathrm{f}(e)] \quad$ was isolated by column chromatography (silica gel, $\mathrm{CH}_{2} \mathrm{Cl}_{2}$ /hexane 10:3) as a yellow solid. Mp 64$66{ }^{\circ} \mathrm{C} ; \mathrm{R}_{f} 0.32$ (silica gel, $\mathrm{CH}_{2} \mathrm{Cl}_{2} /$ hexane 10:3). ${ }^{1} \mathrm{H} \mathrm{NMR}\left(\mathrm{CDCl}_{3}\right): \delta 1.63$ (dtd, $J 13.1,13.1,3.6$ 
$\mathrm{Hz}, \mathrm{H6}^{\mathrm{ax}}$ ), 1.77 (dtd, $J 11.6,13.1,3.6 \mathrm{~Hz}, \mathrm{H} 7^{\mathrm{ax}}$ ), 1.90 (q, $J 12.2 \mathrm{~Hz}, \mathrm{H} 4^{\mathrm{ax}}$ ), 2.23 (ddq, $J 13.6,1.8$, $3.5 \mathrm{~Hz}, \mathrm{H6}^{\mathrm{eq}}$ ), 2.28 (dq, $J 13.1,3.4 \mathrm{~Hz}, \mathrm{H}^{\mathrm{eq}}$ ), $2.47\left(\mathrm{dtd}, J 12.9,3.4,1.8 \mathrm{~Hz}, \mathrm{H} 4^{\mathrm{eq}}\right), 2.55(\mathrm{tt}, J$ 12.3, $3.8 \mathrm{~Hz}, \mathrm{H} 5), 3.68$ (s, 3H; $\mathrm{OCH}_{3}$ ), 4.06 (dt, J 3.5, $\left.12.1 \mathrm{~Hz}, \mathrm{H} 3 \mathrm{a}\right), 4.10$ (dt, J 3.4, $12.1 \mathrm{~Hz}$, $\mathrm{H} 7 \mathrm{a}) ;{ }^{13} \mathrm{C} \mathrm{NMR}\left(\mathrm{CDCl}_{3}\right): \delta 27.70,27.90$ (C6, C7), $31.02(\mathrm{C} 4), 41.87(\mathrm{C} 5), 52.12\left(\mathrm{OCH}_{3}\right), 62.90$, $63.27(\mathrm{C} 3 \mathrm{a}, \mathrm{C} 7 \mathrm{a}), 173.62(\mathrm{C}=\mathrm{O}), 225.92(\mathrm{C}=\mathrm{S})$; HRMS: $\mathrm{C}_{9} \mathrm{H}_{12} \mathrm{O}_{2} \mathrm{~S}_{3}$ requires $[\mathrm{M}+\mathrm{H}]^{+} \mathrm{m} / z$ 249.0078; observed $\mathrm{m} / \mathrm{z} 249.0074$.

$\left(1 S^{*}, 2 S^{*}, 5 S^{*}, 6 S^{*}\right)-5,6-B i s($ ethoxycarbonyl)hexahydro-1,3-benzodithiole-2-thione [2g(ee)] was prepared from epoxide $\mathbf{1 g}$ and was isolated by column chromatography (silica gel, EtOAc/hexane 5:7) as a yellow liquid (7\%). ${ }^{1} \mathrm{H} \mathrm{NMR}\left(\mathrm{CDCl}_{3}\right): \delta 1.25\left(\mathrm{t}, J 7.1 \mathrm{~Hz}, 6 \mathrm{H} ; \mathrm{CH}_{3}\right)$, 1.82-1.93 (m, 2H; H4+H7), 2.56-2.61 (m, 2H; H4+H7), 2.86-2.93 (m, 2H; H5+H6), 4.09-4.14 $(\mathrm{m}, 2 \mathrm{H} ; \mathrm{H} 3 \mathrm{a}+\mathrm{H} 7 \mathrm{a}), 4.15$ (q, $\left.J 7.1 \mathrm{~Hz}, 2 \mathrm{H} ; \mathrm{OCH}_{2}\right), 4.16$ (q, $\left.J 7.1 \mathrm{~Hz}, 2 \mathrm{H} ; \mathrm{OCH}_{2}\right) ;{ }^{13} \mathrm{C} \mathrm{NMR}$ $\left(\mathrm{CDCl}_{3}\right): \delta 14.18\left(\mathrm{CH}_{3}\right), 30.84(\mathrm{C} 4, \mathrm{C} 7), 43.83(\mathrm{C} 5, \mathrm{C} 6), 61.47\left(\mathrm{OCH}_{2}\right), 62.29(\mathrm{C} 3 \mathrm{a}, \mathrm{C} 7 \mathrm{a})$, $172.51(\mathrm{C}=\mathrm{O}), 225.10(\mathrm{C}=\mathrm{S})$; HRMS: $\mathrm{C}_{13} \mathrm{H}_{18} \mathrm{O}_{4} \mathrm{~S}_{3}$ requires $[\mathrm{M}+\mathrm{H}]^{+} \mathrm{m} / \mathrm{z}$ 335.0446; observed $\mathrm{m} / \mathrm{z}$ 335.0452 .

5,6-Bis(methoxycarbonyl)hexahydro-1,3-benzodithiole-2-thiones [ $2 \mathrm{~h}(e e)$ and $2 \mathrm{~h}(e a)]$ were obtained in 10:1 ratio from either $\mathbf{1 h}$-anti or $\mathbf{1 h}-\mathbf{s y n}$ epoxide.

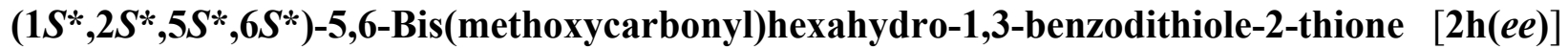
was isolated by column chromatography (silica gel, EtOAc/hexane 3:7) as a yellow solid (50\%). Alternatively, $\mathbf{2 h}(\boldsymbol{e e})$ was purified by crystallization from $\mathrm{MeOH}$ (yield 46\%). Mp 189-190 ${ }^{\circ} \mathrm{C}$; $\mathrm{R}_{f} 0.48$ (silica gel, EtOAc/hexane 3:7). ${ }^{1} \mathrm{H}$ NMR $\left(\mathrm{CDCl}_{3}\right): \delta 1.83-1.93(\mathrm{~m}, 2 \mathrm{H} ; \mathrm{H} 4+\mathrm{H} 7), 2.56-$ 2.61 (m, 2H; H4+H7), 2.88-2.95 (m, 2H; H5+H6), $3.71\left(\mathrm{~s}, 6 \mathrm{H} ; \mathrm{OCH}_{3}\right), 4.10-4.17(\mathrm{~m}, 2 \mathrm{H}$; $\mathrm{H} 3 \mathrm{a}+\mathrm{H} 7 \mathrm{a}) ;{ }^{13} \mathrm{C} \mathrm{NMR}\left(\mathrm{CDCl}_{3}\right): \delta 30.77(\mathrm{C} 4, \mathrm{C} 7), 43.72(\mathrm{C} 5, \mathrm{C} 6), 52.56\left(\mathrm{OCH}_{3}\right), 62.17(\mathrm{C} 3 \mathrm{a}$, $\mathrm{C} 7 \mathrm{a}), 172.97(\mathrm{C}=\mathrm{O}), 224.81(\mathrm{C}=\mathrm{S})$; HRMS: $\mathrm{C}_{11} \mathrm{H}_{14} \mathrm{O}_{4} \mathrm{~S}_{3}$ requires $[\mathrm{M}+\mathrm{H}]^{+} \mathrm{m} / z \quad 307.0133$; observed $m / z 307.0116$.

$\left(1 S^{*}, 2 S^{*}, 5 S^{*}, 6 R^{*}\right)-5,6-\mathrm{Bis}($ methoxycarbonyl)hexahydro-1,3-benzodithiole-2-thione [2h(ea)] was isolated by column chromatography (silica gel, EtOAc/hexane 3:7) as a yellow oil (5\%). $\mathrm{R}_{f}$ 0.31 (silica gel, EtOAc/hexane 3:7). ${ }^{1} \mathrm{H}$ NMR $\left(\mathrm{CDCl}_{3}\right): \delta 2.02\left(\mathrm{ddd}, J 13.6,12.4,5.1 \mathrm{~Hz}, \mathrm{H} 4^{\mathrm{ax}}\right)$, 2.34 (dt, $J 13.4,12.4 \mathrm{~Hz}, \mathrm{H}^{\mathrm{ax}}$ ), 2.57 (dtd, $\left.J 3.5,3.7,0.9 \mathrm{~Hz}, \mathrm{H} 7^{\mathrm{eq}}\right), 2.65-2.70\left(\mathrm{~m}, 2 \mathrm{H} ; \mathrm{H}^{\mathrm{eq}}+\mathrm{H} 6\right)$, 3.50 (m, H5), $3.71\left(\mathrm{~s}, 3 \mathrm{H} ; \mathrm{OCH}_{3}\right), 3.73\left(\mathrm{~s}, 3 \mathrm{H}, \mathrm{OCH}_{3}\right), 4.07-4.15(\mathrm{~m}, 2 \mathrm{H} ; \mathrm{H} 3 \mathrm{a}+\mathrm{H} 7 \mathrm{a}) ;{ }^{13} \mathrm{C} \mathrm{NMR}$ $\left(\mathrm{CDCl}_{3}\right): \delta 27.28(\mathrm{C} 7), 30.40(\mathrm{C} 4), 41.11(\mathrm{C} 5), 42.97(\mathrm{C} 6), 52.48,52.60\left(\mathrm{OCH}_{3}\right), 59.68,63.16$ $(\mathrm{C} 3 \mathrm{a}, \mathrm{C} 7 \mathrm{a}), 171.88,172.36(\mathrm{C}=\mathrm{O}), 225.40(\mathrm{C}=\mathrm{S})$; HRMS: $\mathrm{C}_{11} \mathrm{H}_{14} \mathrm{O}_{4} \mathrm{~S}_{3}$ requires $[\mathrm{M}+\mathrm{H}]^{+} \mathrm{m} / z$ 307.0133; observed $\mathrm{m} / \mathrm{z} 307.0125$.

$\left(1 S^{*}, 2 S^{*}, 5 S^{*}, 6 R^{*}\right)-2$-Thioxohexahydro-1,3-benzodithiole-cis-5,6-dicarboximide (2i) was prepared from epoxide 1i-syn after $72 \mathrm{~h}$ at $40{ }^{\circ} \mathrm{C}$ and was isolated by column chromatography (silica gel, $\mathrm{CH}_{2} \mathrm{Cl}_{2} / \mathrm{MeOH}$ 9:1) as a yellow solid (56\%). Mp 220-221 ${ }^{\circ} \mathrm{C}$; $\mathrm{R}_{f} 0.32$ (silica gel, $\mathrm{CH}_{2} \mathrm{Cl}_{2} / \mathrm{MeOH}$ 9:1). ${ }^{1} \mathrm{H}$ NMR (CD ${ }_{3} \mathrm{OD}$ ): $\delta 1.76$ (q, $J 12.5 \mathrm{~Hz}, \mathrm{H}^{\mathrm{ax}}$ ), 2.04 (ddd, $J$ 13.7, 12.9, 7.5 $\mathrm{Hz}, \mathrm{H}^{\mathrm{ax}}$ ), 2.63 (ddd, $J 13.4,7.4,3.3 \mathrm{~Hz}, \mathrm{H}^{\mathrm{eq}}$ ), 2.78 (ddd, $\left.J 13.8,4.0,1.3 \mathrm{~Hz}, \mathrm{H}^{\mathrm{eq}}\right), 3.09$ (dt, $J$ 11.7, 7.6 Hz, H5), 3.34 (dt, J 7.7, $1.1 \mathrm{~Hz}, \mathrm{H} 6$ ), 4.13 (dt, J 12.4, 4.1 Hz, H7a), 4.28 (dt, $J$ 12.3, 3.1 $\mathrm{Hz}, \mathrm{H} 3 \mathrm{a}) ;{ }^{13} \mathrm{C}$ NMR $\left(\mathrm{CD}_{3} \mathrm{OD}\right): \delta 24.09,29.79$ (C4, C7), 40.44 (C5, C6), 59.96, 60.45 (C3a, 
C7a), 178.73, $179.51(\mathrm{C}=\mathrm{O}), 225.76(\mathrm{C}=\mathrm{S})$; HRMS: $\mathrm{C}_{9} \mathrm{H}_{9} \mathrm{NO}_{2} \mathrm{~S}_{3}$ requires $[\mathrm{M}+\mathrm{H}]^{+} \mathrm{m} / z$ 259.9873; observed $\mathrm{m} / \mathrm{z} 259.9867$.

$\left(1 S^{*}, 3 R^{*}, 4 S^{*}, 6 R^{*}\right)$-7-Thiabicyclo[4.1.0]heptane-cis-3,4-dicarboximide

(3,4-epithiohexahydrophthalimide) was obtained in the reaction of epoxide 1i-syn with potassium ethyl xanthogenate after $15 \mathrm{~h}$ at $40{ }^{\circ} \mathrm{C}$ and was isolated by column chromatography (silica gel, $\left.\mathrm{CH}_{2} \mathrm{Cl}_{2} / \mathrm{MeOH} 9: 1\right)$ as a yellow solid (52\%). Mp 207-209 ${ }^{\circ} \mathrm{C}$. Configuration was established based on the similarity of the ${ }^{1} \mathrm{H}$ NMR spectra of this thiirane and 1i-anti epoxide. ${ }^{1} \mathrm{H}$ NMR (CD ${ }_{3} \mathrm{OD}$ ): $\delta$ 2.07-2.12 (m, 2H; H2+H6), 2.47-2.55 (m, 2H; H2+H5), 2.83-2.89 (m, 2H; H3+H4), 3.24-3.27 (m, 2H; H1+H6); ${ }^{13} \mathrm{C}$ NMR (CD $\left.{ }_{3} \mathrm{OD}\right): \delta 23.73(\mathrm{C} 2, \mathrm{C} 5), 32.90(\mathrm{C} 3, \mathrm{C} 4), 36.79(\mathrm{C} 1$, C6), $182.04(\mathrm{C}=\mathrm{O})$; HRMS: $\mathrm{C}_{8} \mathrm{H}_{9} \mathrm{NO}_{2} \mathrm{~S}$ requires $[\mathrm{M}+\mathrm{H}]^{+} \mathrm{m} / z$ 184.0432; observed $\mathrm{m} / z$ 184.0420.

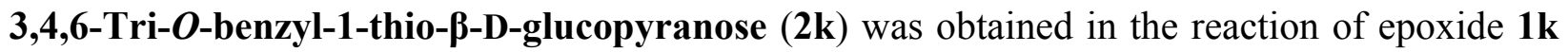
with potassium ethyl xanthogenate after $2 \mathrm{~h}$ at $45{ }^{\circ} \mathrm{C}$ and was isolated by column chromatography (silica gel, $\mathrm{CH}_{2} \mathrm{Cl}_{2} /$ EtOAc 10:0.5) as a colorless oil (37\%). $\mathrm{R}_{f} 0.19$ (silica gel, $\mathrm{CHCl}_{3} / \mathrm{EtOAc}$ 10:1). ${ }^{1} \mathrm{H} \mathrm{NMR}\left(\mathrm{CDCl}_{3}\right): \delta 2.19(\mathrm{~d}, J 9.7 \mathrm{~Hz}, \mathrm{SH}), 2.43(\mathrm{~d}, J 2.1 \mathrm{~Hz}, \mathrm{OH}), 3.40(\mathrm{dt}, J$ 9.0, $2.1 \mathrm{~Hz}$, H2), 3.49 (ddd, J 9.8, 4.3, 2.0 Hz, H5), 3.53 (t, J 8.9 Hz, H3), 3.66 (dd, J 9.4 Hz, H4), 3.68-3.76 (m, 2H6), 4.33 (t, J 9.5 Hz, H1), 4.52 (d, J $10.7 \mathrm{~Hz}, 1 \mathrm{H} ; \mathrm{CH}_{2}$, benzyl), 4.54 (d, J $12.2 \mathrm{~Hz}, 1 \mathrm{H}$; $\mathrm{CH}_{2}$, benzyl), 4.61 (d, $J 12.2 \mathrm{~Hz}, 1 \mathrm{H} ; \mathrm{CH}_{2}$, benzyl), 4.81 (d, $J 10.7 \mathrm{~Hz}, 1 \mathrm{H} ; \mathrm{CH}_{2}$, benzyl), 4.85 (d, J 11.3 Hz, 1H; $\mathrm{CH}_{2}$, benzyl), 4.91 (d, $J 11.3 \mathrm{~Hz}, 1 \mathrm{H} ; \mathrm{CH}_{2}$, benzyl), 7.12-7.16 (m, 2H), 7.25$7.38(\mathrm{~m}, 13 \mathrm{H}) ;{ }^{13} \mathrm{C} \mathrm{NMR}\left(\mathrm{CDCl}_{3}\right): \delta 68.73\left(\mathrm{CH}_{2}\right), 73.64,75.17,75.34\left(\mathrm{CH}_{2}\right.$, benzyl); $77.40(\mathrm{C} 4)$, 77.67 (C2), 79.82 (C5), 81.02 (C1), 85.69 (C3), 127.83, 127.92, 127.94, 128.05, 128.50, 128.52, 128.64, 137.99, 138.02, 138.56 (C aromatic) (Lit. ${ }^{1} \mathrm{H}$ NMR and ${ }^{13} \mathrm{C}$ NMR for a mixture of $\alpha$ - and $\beta$-isomers see in SI for ${ }^{19}$ ); HRMS: $\mathrm{C}_{27} \mathrm{H}_{30} \mathrm{O}_{5} \mathrm{~S}$ requires $\left[\mathrm{M}+\mathrm{NH}_{4}\right]^{+} \mathrm{m} / z$ 484.2158, $[\mathrm{M}+\mathrm{H}]^{+} \mathrm{m} / z$ 467.1892, $\left[\mathrm{M}-\mathrm{H}_{2} \mathrm{O}+\mathrm{H}\right]^{+} \mathrm{m} / \mathrm{z}$ 449.1787; observed $\mathrm{m} / \mathrm{z}$ 484.2110, 467.1933, 449.1808.

trans-4,5-Dimethyl-1,3-dithiolane-2-thione (2n) was prepared from cis-1,2-dimethyloxirane 1n and was isolated by column chromatography (silica gel, EtOAc/hexane 3:7) as a yellow solid (43\%). Mp 40-42 ${ }^{\circ} \mathrm{C}$ (Lit. ${ }^{13} \mathrm{Mp} 41.5-42.5{ }^{\circ} \mathrm{C}$ ); $\mathrm{R}_{f} 0.56$ (silica gel, EtOAc/hexane 3:7). ${ }^{1} \mathrm{H}$ NMR $\left(\mathrm{CDCl}_{3}\right): \delta 1.58\left(\mathrm{~m}, 6 \mathrm{H}, \mathrm{CH}_{3}\right), 4.10(\mathrm{~m}, 2 \mathrm{H}, \mathrm{H} 4+\mathrm{H} 5)$, $\left(\right.$ Lit. $\left.{ }^{20}{ }^{1} \mathrm{H} \mathrm{NMR}\right) ;{ }^{13} \mathrm{C} \mathrm{NMR}\left(\mathrm{CDCl}_{3}\right): \delta$ $18.58\left(\mathrm{CH}_{3}\right), 61.38(\mathrm{C} 4, \mathrm{C} 5), 226.41(\mathrm{C}=\mathrm{S})$; HRMS: $\mathrm{C}_{5} \mathrm{H}_{8} \mathrm{~S}_{3}$ requires $[\mathrm{M}+\mathrm{H}]^{+} \mathrm{m} / \mathrm{z} 164.9866$; observed $\mathrm{m} / \mathrm{z} 164.9858$.

4,4-Dimethyl-1,3-dithiolane-2-thione (2o) was prepared from 1,1-dimethyloxirane 10 and was isolated by column chromatography (silica gel, $\mathrm{CH}_{2} \mathrm{Cl}_{2}$ /hexane 10:3) as a yellow liquid (30\%). $\mathrm{R}_{f}$ 0.77 (silica gel, $\mathrm{CH}_{2} \mathrm{Cl}_{2} /$ hexane 10:3). ${ }^{1} \mathrm{H} \mathrm{NMR}\left(\mathrm{CDCl}_{3}\right): \delta 1.73\left(\mathrm{~s}, 6 \mathrm{H}, \mathrm{CH}_{3}\right), 3.74(\mathrm{~s}, 2 \mathrm{H}, \mathrm{H} 5)$, (Lit. $\left.{ }^{21}{ }^{1} \mathrm{H} \mathrm{NMR}\right) ;{ }^{13} \mathrm{C} \mathrm{NMR}\left(\mathrm{CDCl}_{3}\right): \delta 27.58\left(\mathrm{CH}_{3}\right), 55.76(\mathrm{C} 5), 66.22(\mathrm{C} 4), 227.76(\mathrm{C}=\mathrm{S})$; HRMS: $\mathrm{C}_{5} \mathrm{H}_{8} \mathrm{~S}_{3}$ requires $[\mathrm{M}+\mathrm{H}]^{+} \mathrm{m} / z$ 164.9866; observed $\mathrm{m} / z$ 164.9891.

cis-4,5-Diphenyl-1,3-dithiolane-2-thione (2r) was prepared from trans-1,2-diphenyloxirane 1r and was isolated by column chromatography (silica gel, EtOAc/hexane 3:7) as a yellow solid

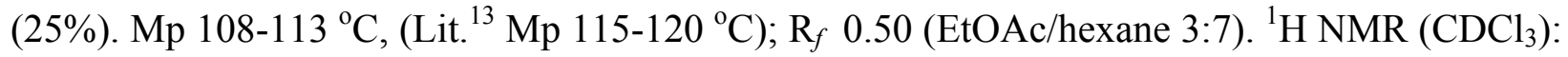
$\delta 5.75$ (s, 2H; H4+H5), 6.97-7.00 (m, 4H; phenyl), 7.15 (t, J 7.6 Hz, 4H; phenyl), 7.22 (tt, J 7,4, $1.2 \mathrm{~Hz} ; 2 \mathrm{H}$, phenyl); ${ }^{13} \mathrm{C} \mathrm{NMR}\left(\mathrm{CDCl}_{3}\right): \delta 67.92$ (C4, C5), 128.35, 128.68, $128.83133 .06(\mathrm{C}$, phenyl), $227.52(\mathrm{C}=\mathrm{S})$; HRMS: $\mathrm{C}_{15} \mathrm{H}_{12} \mathrm{~S}_{3}$ requires $[\mathrm{M}+\mathrm{H}]^{+} \mathrm{m} / \mathrm{z} 289.0179 ;$ observed $\mathrm{m} / \mathrm{z}$ 
289.0171. trans-2,3-Diphenylthiirane was obtained in the reaction of trans-epoxide 1r with potassium ethyl xanthogenate after $15 \mathrm{~h}$ at $40{ }^{\circ} \mathrm{C}$ and isolated by column chromatography $\left(\mathrm{Al}_{2} \mathrm{O}_{3}\right.$, hexane) as a white solid (38\%). Mp 52-54 ${ }^{\circ} \mathrm{C}$ (Lit. $\left.{ }^{51} \mathrm{Mp} \mathrm{53-54}{ }^{\circ} \mathrm{C}\right) ; \mathrm{R}_{f} 0.61\left(\mathrm{Al}_{2} \mathrm{O}_{3}\right.$, hexane). ${ }^{1} \mathrm{H}$ NMR $\left(\mathrm{CDCl}_{3}\right): \delta 3.97(\mathrm{~s}, 2 \mathrm{H} ; \mathrm{H} 2+\mathrm{H} 3), 7.27-7.30(\mathrm{~m}, 2 \mathrm{H}$; phenyl), 7.32-7.39 (m, $8 \mathrm{H}$; phenyl) (Lit. $\left.{ }^{52} \mathrm{H} \mathrm{NMR}\right) ;{ }^{13} \mathrm{C} \mathrm{NMR}\left(\mathrm{CDCl}_{3}\right): \delta 45.54$ (C2, C3), 127.09, 127.89, 128.74, 138.77 (C, phenyl); HRMS: $\mathrm{C}_{14} \mathrm{H}_{12} \mathrm{~S}$ requires $[\mathrm{M}+\mathrm{H}]^{+} \mathrm{m} / \mathrm{z} 213.0738$; observed $\mathrm{m} / z$ 213.0708.

4-n-Butyl-1,3-dithiolane-2-thione (2s) was prepared from 1,2-epoxyhexane $1 \mathrm{~s}$ and was isolated by column chromatography ( silica gel, $\mathrm{CH}_{2} \mathrm{Cl}_{2}$ /hexane $2: 1$ ) as a yellow liquid $(52 \%) . \mathrm{R}_{f} 0.52$ (silica gel, $\mathrm{CH}_{2} \mathrm{Cl}_{2} /$ hexane 1:1). ${ }^{1} \mathrm{H} \mathrm{NMR}\left(\mathrm{CDCl}_{3}\right): \delta 0.91\left(\mathrm{t}, J 7.1 \mathrm{~Hz}, 3 \mathrm{H} ; \mathrm{CH}_{3}\right), 1.38(\mathrm{~m}, 4 \mathrm{H}$; $\left.2 \mathrm{CH}_{2}\right), 1.92\left(\mathrm{~m}, 2 \mathrm{H} ; \mathrm{CH}_{2}\right), 3.70\left(\mathrm{dd}, J 11.9,7.9 \mathrm{~Hz}, 1 \mathrm{H} ; \mathrm{CH}_{2} \mathrm{~S}\right), 3.95(\mathrm{dd}, J 11.9,5.5 \mathrm{~Hz}, 1 \mathrm{H}$; $\left.\mathrm{CH}_{2} \mathrm{~S}\right), 4.38$ (tt, $J$ 8.0, $5.5 \mathrm{~Hz}, 1 \mathrm{H}$; CHS); ${ }^{13} \mathrm{C} \mathrm{NMR}\left(\mathrm{CDCl}_{3}\right): \delta 13.92\left(\mathrm{CH}_{3}\right), 22.43\left(\mathrm{CH}_{2}\right), 30.48$ $\left(\mathrm{CH}_{2}\right), 33.33\left(\mathrm{CH}_{2}\right), 48.29\left(\mathrm{CH}_{2} \mathrm{~S}\right), 61.07$ (CHS), $228.06(\mathrm{C}=\mathrm{S})$ (Lit. $\left.{ }^{2}{ }^{1} \mathrm{H} \mathrm{NMR},{ }^{13} \mathrm{C} \mathrm{NMR}\right)$; HRMS: $\mathrm{C}_{7} \mathrm{H}_{12} \mathrm{~S}_{3}$ requires $[\mathrm{M}+\mathrm{H}]^{+} \mathrm{m} / z$ 193.0179; observed $m / z$ 193.0163.

\section{Ethyl 4,6-di-O-acetyl-2,3-epithio-2,3-dideoxy- $\alpha$-D-allopyranoside (2I)}

Potassium ethyl xanthogenate $(130 \mathrm{mg}, 0.8 \mathrm{mmol})$ was dissolved in $1 \mathrm{~mL}$ of $\mathrm{MeOH}$ under $\mathrm{Ar}$ atmosphere and solution of manno-epoxide 11 (110 mg, $0.4 \mathrm{mmol})$ in $2 \mathrm{~mL}$ of $\mathrm{MeOH}$ was added at $40{ }^{\circ} \mathrm{C}$ while stirring. The mixture was stirred at this temperature for $24 \mathrm{~h}$ until complete conversion of the epoxide, as monitored by TLC. The reaction mixture was passed through a layer of silica gel and concentrated under reduced pressure. The residue was dissolved in dry $\mathrm{CH}_{2} \mathrm{Cl}_{2}$ and acetic anhydride $(0.5 \mathrm{~mL})$ was added to the solution at $0{ }^{\circ} \mathrm{C}$ under stirring followed by pyridine $(0.1 \mathrm{~mL})$. The reaction mixture was allowed to warm up to room temperature and was stirred for $24 \mathrm{~h}$. The solvent was removed on a rotary evaporator. The product was isolated by column chromatography (silica gel, hexane/EtOAc gradient washing 5:1 $\rightarrow 5: 3$ ) as a colorless oil (38 mg, 32\%). $\mathrm{R}_{f} 0.24$ (silica gel, hexane/EtOAc 4:1). ${ }^{1} \mathrm{H}$ NMR $\left(\mathrm{CDCl}_{3}\right): \delta 1.22(\mathrm{t}, J 7.1 \mathrm{~Hz}$, $3 \mathrm{H} ; \mathrm{CH}_{3}$, ethyl), 2.05 (s, 3H; $\mathrm{CH}_{3}$, acetyl), 2.08 (s, 3H; $\mathrm{CH}_{3}$, acetyl), 3.54 (dd, J 6.7, 5.2 Hz, H2), 3.59 (dq, $J$ 10.0, 7.1 Hz, 1H; $\mathrm{CH}_{2}$, ethyl), 3.62 (dd, J 6.7, 4.1 Hz, H3), 3.76 (dq, J 10.0, 7.1 Hz, $1 \mathrm{H} ; \mathrm{CH}_{2}$, ethyl), 4.03 (ddd, $J$ 9.9, 5.1, 2.2 Hz, H5), 4.09 (dd, $J 12.1,2.2 \mathrm{~Hz}, \mathrm{H} 6$ ), 4.18 (dd, $J$ 12.1, 5.1 Hz, H6), 5.19 (dd, J 9.8, 4.1 Hz, H4), 5.27 (d, J 5.1 Hz, H1) (the spectrum is similar to the reported ${ }^{48}{ }^{1} \mathrm{H}$ NMR spectrum of the corresponding allo-epoxide); ${ }^{13} \mathrm{C} \mathrm{NMR}\left(\mathrm{CDCl}_{3}\right): \delta 15.19$ $\left(\mathrm{CH}_{3}\right.$, ethyl), $20.86\left(\mathrm{CH}_{3}\right.$, acetyl), $21.06\left(\mathrm{CH}_{3}\right.$, acetyl), $35.72(\mathrm{C} 3), 38.72(\mathrm{C} 2), 62.76(\mathrm{C} 6), 63.18$ (C5), $63.76\left(\mathrm{CH}_{2}\right.$, ethyl), 67.10 (C4), $92.37(\mathrm{C} 1), 170.43(\mathrm{C}=\mathrm{O}), 170.80(\mathrm{C}=\mathrm{O})$; HRMS: $\mathrm{C}_{12} \mathrm{H}_{18} \mathrm{O}_{6} \mathrm{~S}$ requires $[\mathrm{M}+\mathrm{H}]^{+} \mathrm{m} / \mathrm{z}$ 291.0902, $\left[\mathrm{C}_{10} \mathrm{H}_{13} \mathrm{O}_{5} \mathrm{~S}\right]^{+} \mathrm{m} / \mathrm{z}$ 245.0484; observed $\mathrm{m} / \mathrm{z} 291.0912$, 245.0493.

Oxidation of trithiocarbonates. Trithiocarbonate $(0.5 \mathrm{mmol})$ was dissolved in $2 \mathrm{~mL}$ of dry $\mathrm{CHCl}_{3}$, and solution of $\mathrm{Br}_{2}(2 \mathrm{mmol})$ in $2 \mathrm{~mL}$ of $\mathrm{CHCl}_{3}$ was added dropwise at $0{ }^{\circ} \mathrm{C}$ while stirring. The mixture was allowed to warm to room temperature $\left(20{ }^{\circ} \mathrm{C}\right)$ and was stirred for 6-12 $\mathrm{h}$ until complete conversion of the starting material as monitored by TLC. After addition of 20 $\mathrm{mL} \mathrm{CHCl}_{3}$, an orange precipitate was removed by suction filtration. The filtrate was washed with dilute aqueous $\mathrm{NaHCO}_{3}(10 \mathrm{~mL})$ followed by saturated $\mathrm{NaCl}(10 \mathrm{~mL})$ and dried over anhydrous 
$\mathrm{Na}_{2} \mathrm{SO}_{4}$. The solvent was removed on a rotary evaporator. Purification of the product was achieved by column chromatography.

Hexahydro-1,3-benzodithiol-2-one (3a) was prepared by oxidation of trithiocarbonate 2a with $\mathrm{Br}_{2}$ and was isolated by column chromatography (silica gel, $\mathrm{CH}_{2} \mathrm{Cl}_{2} /$ hexane $3: 1$ ) as a white solid (60\%). Mp 106-108 ${ }^{\circ} \mathrm{C} ; \mathrm{R}_{f} 0.55$ (silica gel, $\mathrm{CH}_{2} \mathrm{Cl}_{2} /$ hexane 3:1). ${ }^{1} \mathrm{H}$ NMR $\left(\mathrm{CDCl}_{3}\right): \delta$ 1.49-1.54 (m, 2H; H5+H6), 1.63-1.72 (m, 2H; H4+H7), 1.90-1.95(m, 2H; H5+H6), 2.14-2.19 (m, 2H; $\mathrm{H} 4+\mathrm{H} 7), 3.79-3.85$ (m, 2H; H3a+7a); ${ }^{13} \mathrm{C} \mathrm{NMR}\left(\mathrm{CDCl}_{3}\right): \delta 25.63(\mathrm{C} 5, \mathrm{C} 6), 29.51(\mathrm{C} 4, \mathrm{C} 7)$, 58.46 (C3a, C7a), $195.88(\mathrm{C}=\mathrm{S})$, (Lit. ${ }^{14}{ }^{1} \mathrm{H}$ NMR); HRMS: $\mathrm{C}_{7} \mathrm{H}_{10} \mathrm{OS}_{2}$ requires $[2 \mathrm{M}+\mathrm{H}]^{+} \mathrm{m} / z$ 349.0424, $[\mathrm{M}+\mathrm{H}]^{+} \mathrm{m} / \mathrm{z}$ 175.0251; observed $\mathrm{m} / \mathrm{z}$ 349.0403, 175.0253 .

$\left(1 S^{*}, 2 S^{*}, 5 S^{*}, 6 S^{*}\right)-5,6$-Bis(methoxycarbonyl)-hexahydro-1,3-benzodithiol-2-one [3h(ee)] was prepared by oxidation of trithiocarbonate $\mathbf{2 h}(\boldsymbol{e e})$ with $\mathrm{Br}_{2}$ and isolated by column chromatography (silica gel, $\mathrm{CH}_{2} \mathrm{Cl}_{2}$ ) as a white solid (75\%). Mp 130-132 ${ }^{\circ} \mathrm{C} ; \mathrm{R}_{f} 0.23$ (silica gel, $\left.\mathrm{CH}_{2} \mathrm{Cl}_{2}\right) .{ }^{1} \mathrm{H} \mathrm{NMR}\left(\mathrm{CDCl}_{3}\right): \delta 1.78-1.88(\mathrm{~m}, 2 \mathrm{H} ; \mathrm{H} 4+\mathrm{H} 7), 2.54-2.59(\mathrm{~m}, 2 \mathrm{H} ; \mathrm{H} 4+\mathrm{H} 7), 2.91-2.97$ (m, 2H; H5+H6), 3.69 (s, 6H; $\left.\mathrm{OCH}_{3}\right), 3.80-3.86(\mathrm{~m}, 2 \mathrm{H} ; \mathrm{H} 3 \mathrm{a}+\mathrm{H} 7 \mathrm{a}) ;{ }^{13} \mathrm{C} \mathrm{NMR}\left(\mathrm{CDCl}_{3}\right): \delta 31.19$ (C4, C7), 44.00 (C5, C6), $52.51\left(\mathrm{OCH}_{3}\right), 56.15(\mathrm{C} 3 \mathrm{a}, \mathrm{C} 7 \mathrm{a}), 172.96(\mathrm{C}=\mathrm{O}), 194.15(\mathrm{SSC}=\mathrm{O})$; HRMS: $\mathrm{C}_{11} \mathrm{H}_{14} \mathrm{O}_{5} \mathrm{~S}_{2}$ requires $[\mathrm{M}+\mathrm{H}]^{+} \mathrm{m} / z$ 291.0361; observed $\mathrm{m} / z$ 291.0354. The same product was obtained in reactions of trithiocarbonate $\mathbf{2 h}(e e)$ (1 equiv) with DDQ (4 equiv) in dry THF (yield $45 \%$, and $32 \%$ recovered $\mathbf{2 h}(\boldsymbol{e} e)$ ) and with $\mathrm{NBS}$ (4 equiv) in dry $\mathrm{CHCl}_{3}$ (yield 23\%).

\section{Methanolysis of epoxide $1 \mathrm{i}$}

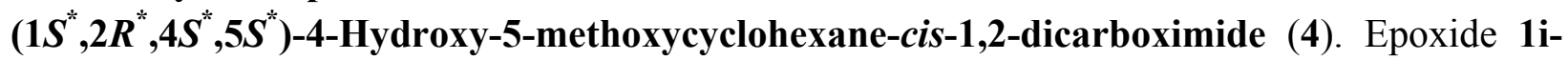
syn $(35 \mathrm{mg}, 0.2 \mathrm{mmol})$ was dissolved in methanol $(1 \mathrm{~mL})$, and $\mathrm{H}_{2} \mathrm{SO}_{4}$ in methanol $(1: 3 \mathrm{v} / \mathrm{v}, 0.1$ $\mathrm{mL}$ ) was added at room temperature. The mixture was stirred for $14 \mathrm{~h}$, then diluted with $\mathrm{CHCl}_{3}$ $(30 \mathrm{~mL})$ and washed with saturated $\mathrm{NaHCO}_{3}(5 \mathrm{~mL})$. Organic phase was dried over $\mathrm{Na}_{2} \mathrm{SO}_{4}$, and solvent was removed on a rotary evaporator yielding $30 \mathrm{mg}$ of white solid (75\%). $\mathrm{R}_{f} 0.41$ (silica gel, $\left.\mathrm{CHCl}_{3} / \mathrm{MeOH} 10: 1\right) .{ }^{1} \mathrm{H} \mathrm{NMR}\left(\mathrm{CDCl}_{3}\right): \delta 1.75$ (ddd, $J 14.2,7.6,6.4 \mathrm{~Hz}, 2 \mathrm{H} ; \mathrm{H}^{\mathrm{ax}}+\mathrm{H}^{\mathrm{ax}}$ ), 2.25 (ddd, $J$ 14.3, 7.3, 3.6 Hz, H6 ${ }^{\mathrm{eq}}$ ), 2.37 (ddd, $J 14.2,6.2,4.1 \mathrm{~Hz}, \mathrm{H} 3^{\mathrm{eq}}$ ), 2.94 (q, $J 7.6 \mathrm{~Hz}, \mathrm{H} 2$ ), 3.04 (dt, J 7.7, $6.5 \mathrm{~Hz}, \mathrm{H} 1$ ), 3.18 (ddd, $J$ 7.8, 6.4, $4.0 \mathrm{~Hz}, \mathrm{H} 5), 3.41$ (s, 3H; $\mathrm{OCH}_{3}$ ), 3.73 (ddd, $J$ 7.8, 6.4, $3.7 \mathrm{~Hz}, \mathrm{H} 4) ;{ }^{13} \mathrm{C} \mathrm{NMR}\left(\mathrm{CDCl}_{3}\right)$ : $\delta 24.17$ (C6), 29.07 (C3), 39.15 (C2), 39.21 (C1), $56.91\left(\mathrm{OCH}_{3}\right), 68.74(\mathrm{C} 4), 79.08(\mathrm{C} 5), 179.04,179.14(\mathrm{C}=\mathrm{O})$; HRMS: $\mathrm{C}_{9} \mathrm{H}_{13} \mathrm{NO}_{4}$ requires $[2 \mathrm{M}+\mathrm{H}]^{+} \mathrm{m} / \mathrm{z}$ 399.1767, $[\mathrm{M}+\mathrm{H}]^{+} \mathrm{m} / \mathrm{z}$ 200.0923; observed $\mathrm{m} / \mathrm{z}$ 399.1866, 200.0924.

\section{Acknowledgements}

We thank Prof. O. David Sparkman and Dr. Matthew Curtis for the use of Pacific Massspectrometry Facility, and Dr. Simon Teat for the single crystal measurements. We gratefully acknowledge the support from the Department of Chemistry at University of the Pacific, the NSF Major Research Instrumentation Grant (CHE-0722654) for the funding of JEOL ECA-600 NMR spectrometer, and the general user proposal for beam time at the Advanced Light Source of Lawrence Berkeley National Lab. The Advanced Light Source is supported by the Director, 
Office of Science, and Office of Basic Energy Sciences of the U.S. Department of Energy under Contract No. DE-AC02-05CH11231.

\section{Supplementary data}

Available information: X-ray crystallographic data and selected NMR spectra. Supplementary data associated with this article can be found with the online version.

\section{References}

1. Dotsenko, I. A.; Samoshin, V. V. Abstracts of Papers, 245th ACS National Meeting \& Exposition; American Chemical Society: New Orleans, LA, United States, April 7-11, 2013; pp. ORGN-812.

2. Clegg, W.; Harrington, R. W.; North, M.; Villuendas, P. J. Org. Chem. 2010, 75, 6201-6207; and references therein. http://dx.doi.org/10.1021/jo101121h

3. Knight, J. G.; Ed. Compounds with Four and Three Carbon-Heteroatom Bonds. [In: Science of Synthesis; 2005, v.18]; Georg Thieme Verlag: Stuttgart, 2005; Vol. 18.

4. Ishii, A.; Asami, S.; Fujiwara, Y.; Ono, A.; Nakata, N. Heteroat. Chem. 2011, 22, 388-396. http://dx.doi.org/10.1002/hc.20695

5. Wang, Y.-M.; Li, B.; Wang, H.; Zhang, Z.-C.; Lu, X.-B. Appl. Organomet. Chem. 2012, 26, 614-618. http://dx.doi.org/10.1002/aoc.2908

6. Motokucho, S.; Takeuchi, D.; Sanda, F.; Endo, T. Tetrahedron 2001, 57, 7149-7152. http://dx.doi.org/10.1016/s0040-4020(01)00685-8

7. Rowland, R. G. U.S. Pat. Appl. Publ.; Chemtura Corporation: USA, 2006; 12 pp.

8. Parker, D. K. U.S. Pat. Appl. Publ.; The Goodyear Tire \& Rubber Company: USA, 2006; 6 pp.

9. Tomita, K.; Nagano, M. In Jpn. Tokkyo Koho; Sankyo Co., Ltd.: Japan, 1968; 4 pp.

10. Allais, A.; Girault, P. Fr. (1970), FR 1584710 19700102; Roussel-UCLAF . 1970; 4 pp.

11. Nakazawa, H.; Ohtsuka, M.; Matsuda, H.; Katori, T.; Irinoda, K. Eur. Pat. Appl.; S. S. Pharmaceutical Co., Ltd.: Japan 1989; 9 pp.

12. Daum, S. J. U.S. Pat. Appl. Publ.; Sterling Drug Inc.: USA 1978; 2 pp.

13. Overberger, C. G.; Drucker, A. J. Org. Chem. 1964, 29, 360-366. http://dx.doi.org/10.1021/jo01025a027

14. Taguchi, Y.; Yasumoto, M.; Shibuya, I.; Suhara, Y. Bull. Chem. Soc. Jpn. 1989, 62, 474-478. http://dx.doi.org/10.1246/bcsj.62.474 
15. Satoh, H.; Manabe, S. Chem. Soc. Rev. 2013, 42, 4297-4309.

http://dx.doi.org/10.1039/c3cs35457a

16. Samoshin, V. V. Rev. J. Chem. 2011, 1, 250-274. http://dx.doi.org/10.1134/S2079978011020026

17. Dotsenko, I. A.; Curtis, M.; Samoshina, N. M.; Samoshin, V. V. Tetrahedron 2011, 67, 7470-7478.

http://dx.doi.org/10.1016/j.tet.2011.07.058

18. Dotsenko, I. A.; Samoshin, V. V. "Convenient synthesis of new 1,10-phenanthroline ligands and the dependence of their conformations on complexation"; Abstracts of Papers, 243rd ACS National Meeting \& Exposition, March 25-29, 2012, San Diego, CA, USA.

19. Dere, R. T.; Kumar, A.; Kumar, V.; Zhu, X.-M.; Schmidt, R. R. J. Org. Chem. 2011, 76, 7539-7545.

http://dx.doi.org/10.1021/jo200624e

20. Sugawara, A.; Sato, T.; Sato, R. Bull. Chem. Soc. Jpn. 1989, 62, 339-341. http://dx.doi.org/10.1246/bcsj.62.339

21. Taguchi, Y.; Yanagiya, K.; Shibuya, I.; Suhara, Y. Bull. Chem. Soc. Jpn. 1987, 60, 727-730. http://dx.doi.org/10.1246/bcsj.60.727

22. Samoshin, V. V.; Kudryavtsev, K. V. Tetrahedron Lett. 1994, 35, 7413-7414. http://dx.doi.org/10.1016/0040-4039(94)85328-2

23. Kudryavtsev, K. V.; Lonina, N. N.; Samoshin, V. V. Zh. Org. Khim. 1994, 30, 1360-1364.

24. Samoshin, V. V.; Kudryavtsev, K. V. Izv. Akad. Nauk, Ser. Khim. 1995, 188-189.

25. Kudryavtsev, K. V.; Samoshin, V. V. Chem. Heterocycl. Compd. 1997, 33, 121-127.

26. McCasland, G. E.; Zanlungo, A. B.; Durham, L. J. J. Org. Chem. 1974, 39, 1462-1466. http://dx.doi.org/10.1021/jo00924a003

27. Russell, G. A.; Law, W. C.; Zaleta, M. J. Am. Chem. Soc. 1985, 107, 4175-4182. http://dx.doi.org/10.1021/ja00300a016

28. Hu, N. X.; Aso, Y.; Otsubo, T.; Ogura, F. Bull. Chem. Soc. Jpn. 1986, 59, 879-884. http://dx.doi.org/10.1246/bcsj.59.879

29. Aitken, R. A.; Mesher, S. T. E.; Ross, F. C.; Ryan, B. M. Synthesis 1997, 787-791. http://dx.doi.org/10.1055/s-1997-1414

30. Booth, H. Progr. Nucl. Magn. Resonance Spectrosc. 1969, 5, 149-381. http://dx.doi.org/10.1016/0079-6565(69)80013-0

31. Hoye, T. R.; Hanson, P. R.; Vyvyan, J. R. J. Org. Chem. 1994, 59, 4096-4103. http://dx.doi.org/10.1021/jo00094a018

32. Hu, H.; Bradley, S. A.; Krishnamurthy, K. J. Magn. Reson. 2004, 171, 201-206. http://dx.doi.org/10.1016/j.jmr.2004.08.018

33. Thrippleton, M. J.; Keeler, J. Angew. Chem., Int. Ed. 2003, 42, 3938-3941. http://dx.doi.org/10.1002/anie.200351947

34. Culvenor, C. C. J.; Davies, W.; Pausacker, K. H. J. Chem. Soc. 1946, 1050-1052. http://dx.doi.org/10.1039/jr9460001050 
35. Lightner, D. A.; Djerassi, C. Tetrahedron 1965, 21, 583-601. http://dx.doi.org/10.1016/S0040-4020(01)82229-8

36. Zefirov, N. S.; Gurvich, L. G.; Shashkov, A. S.; Krimer, M. Z.; Vorob'eva, E. A. Tetrahedron 1976, 32, 1211-1219. http://dx.doi.org/10.1016/0040-4020(76)80074-9

37. Zefirov, N. S.; Samoshin, V. V.; Palyulin, V. A. Zh. Org. Khim. 1983, 19, 1888-1892.

38. Eliel, E. L.; Wilen, S. H.; Mander, L. N. Stereochemistry of organic compounds; Wiley: New York, 1994.

39. SAINT Frame Integration Software; Bruker AXS, Inc.: Madison, WI, 2008; Vol. v7.60a.

40. SADABS, Program for Absorption Correction of Area Detector Frames; Bruker AXS, Inc.: Madison, WI, 2008.

41. Robinson, P. L.; Barry, C. N.; Kelly, J. W.; Evans, S. A., Jr. J. Am. Chem. Soc. 1985, 107, 5210-5219.

http://dx.doi.org/10.1021/ja00304a030

42. Chan, V. Y.; Clark, C. I.; Giordano, J.; Green, A. J.; Karalis, A.; White, J. M. J. Org. Chem. 1996, 61, 5227-5233.

http://dx.doi.org/10.1021/jo9602480

43. Rickborn, B.; Quartucci, J. J. Org. Chem. 1964, 29, 2476-2477. http://dx.doi.org/10.1021/jo01031a524

44. Harrison, C. R.; Hodge, P. J. Chem. Soc., Perkin Trans. 1 1976, 605-609. http://dx.doi.org/10.1039/p19760000605

45. Brazdova, B.; Tan, N. S.; Samoshina, N. M.; Samoshin, V. V. Carbohydr. Res. 2009, 344, 311-321.

http://dx.doi.org/10.1016/j.carres.2008.11.009

46. Eby, R.; Srivastava, V. K. Carbohydr. Res. 1982, 102, 1-9. http://dx.doi.org/10.1016/s0008-6215(00)88045-3

47. Halcomb, R. L.; Danishefsky, S. J. J. Am. Chem. Soc. 1989, 111, 6661-6666. http://dx.doi.org/10.1021/ja00199a028

48. De las Heras, F. G.; San Felix, A.; Calvo-Mateo, A.; Fernandez-Resa, P. Tetrahedron 1985, 41. 3867-3873. http://dx.doi.org/10.1016/s0040-4020(01)91407-3

49. Gremyachinskiy, D. Total synthesis of beta-aminomethyl C-glycosides and their quinoyl amides; Ph.D. Dissertation, University of the Pacific, California, USA: Stockton, 2002.

50. Gremyachinskiy, D. E.; Samoshin, V. V.; Gross, P. H. Tetrahedron Lett. 2003, 44, $6587-$ 6590. http://dx.doi.org/10.1016/s0040-4039(03)01692-7

51. Ketcham, R.; Shah, V. P. J. Org. Chem. 1963, 28, 229-230. http://dx.doi.org/10.1021/jo01036a511

52. Meyers, A. I.; Ford, M. E. J. Org. Chem. 1976, 41, 1735-1742. http://dx.doi.org/10.1021/jo00872a015 